\title{
Merging Perspectives on Secondary Minerals on Mars: A Review of Ancient Water-Rock Interactions in Gale Crater Inferred from Orbital and In-Situ Observations
}

\author{
Rachel Y. Sheppard ${ }^{1, *}$, , Michael T. Thorpe ${ }^{2}$, Abigail A. Fraeman ${ }^{1}$, Valerie K. Fox ${ }^{3}$ and Ralph E. Milliken ${ }^{4}$ \\ 1 Jet Propulsion Laboratory, California Institute of Technology, Pasadena, CA 91109, USA; \\ abigail.a.fraeman@jpl.nasa.gov \\ 2 JETS Contract, NASA JSC, Texas State University, Houston, TX 77058, USA; michael.t.thorpe@nasa.gov \\ 3 Department of Earth and Environmental Sciences, University of Minnesota-Twin Cities, \\ Minneapolis, MN 55455, USA; vfox@umn.edu \\ 4 Department of Earth, Environmental and Planetary Sciences, Brown University, Providence, RI 02912, USA; \\ ralph_milliken@brown.edu \\ * Correspondence: rachel.y.sheppard@jpl.nasa.gov
}

Citation: Sheppard, R.Y.; Thorpe, M.T.; Fraeman, A.A.; Fox, V.K.; Milliken, R.E. Merging Perspectives on Secondary Minerals on Mars: A Review of Ancient Water-Rock Interactions in Gale Crater Inferred from Orbital and In-Situ Observations. Minerals 2021, 11, 986. https://doi.org/10.3390/min11090986

Academic Editors: Yasuhito Sekine, Elizabeth B. Rampe and Keisuke Fukushi

Received: 24 July 2021

Accepted: 24 August 2021

Published: 9 September 2021

Publisher's Note: MDPI stays neutral with regard to jurisdictional claims in published maps and institutional affiliations.

Copyright: (c) 2021 by the authors. Licensee MDPI, Basel, Switzerland. This article is an open access article distributed under the terms and conditions of the Creative Commons Attribution (CC BY) license (https:// creativecommons.org/licenses/by/ $4.0 /)$.

\begin{abstract}
Phyllosilicates, sulfates, and Fe oxides are the most prevalent secondary minerals detected on Mars from orbit and the surface, including in the Mars Science Laboratory Curiosity rover's field site at Gale crater. These records of aqueous activity have been investigated in detail in Gale crater, where Curiosity's X-ray diffractometer allows for direct observation and detailed characterization of mineral structure and abundance. This capability provides critical ground truthing to better understand how to interpret Martian mineralogy inferred from orbital datasets. Curiosity is about to leave behind phyllosilicate-rich strata for more sulfate-rich terrains, while the Mars 2020 Perseverance rover is in its early exploration of ancient sedimentary strata in Jezero crater. It is thus an appropriate time to review Gale crater's mineral distribution from multiple perspectives, utilizing the range of chemical, mineralogical, and spectral measurements provided by orbital and in situ observations. This review compares orbital predictions of composition in Gale crater with higher fidelity (but more spatially restricted) in situ measurements by Curiosity, and we synthesize how this information contributes to our understanding of water-rock interaction in Gale crater. In the context of combining these disparate spatial scales, we also discuss implications for the larger understanding of martian surface evolution and the need for a wide range of data types and scales to properly reconstruct ancient geologic processes using remote methods.
\end{abstract}

Keywords: Mars; secondary mineralogy; Gale crater; phyllosilicates; sulfates; diagenesis

\section{Introduction}

The past several decades of Mars exploration have demonstrated the breadth and variety of sedimentary processes on the surface of that planet (e.g., [1-3]). Mechanisms for sediment generation, transport, and lithification are numerous and include impact, eolian, volcanic (e.g., ash), fluvial, lacustrine, thermal cycling, burial, cementation, early and late diagenetic processes, to name a few. Many of these processes are observed at multiple locations across the martian surface in orbital data, and landed missions have allowed detailed documentation and characterization at a handful of locations (e.g., [4-10]). The majority of the Martian crust is of igneous/volcanic origin (or impact-modified equivalents), but orbital and in situ data also demonstrate that sedimentary deposits on Mars are mineralogically diverse, often containing secondary and hydrated minerals that reflect the geochemical conditions of their formation and evolution (e.g., [11-13]). The suite of sedimentary strata exposed at the modern surface have become a primary target for current and future landed exploration. This is particularly true for rover missions focused on assessing the habitability and organic preservation potential of Mars, where sedimentary 
environments and minerals of non-igneous origin (i.e., secondary minerals) are of great interest (e.g., $[14,15])$. As for Earth, understanding the origin, composition, post-depositional history, and ages of sedimentary strata on Mars will be crucial for unraveling its geologic history and understanding how that history records the planet's climatic evolution.

In this context, the framework of [16] provides a useful starting point to understand how secondary minerals in sedimentary deposits may be linked to geologic and paleoclimatic processes on Mars over the last $>4$ billion years. This model posits that the evolution of Mars can be viewed as three distinct periods of time recorded by the global distribution of different mineral assemblages as viewed from orbit. The crater-count based Noachian, Hesperian, and Amazonian age periods roughly correspond to mineralogical time periods referred to as the phyllosian, theiikian, and siderikian. These three mineralogical periods correspond to terrains whose orbital-based visible-near infrared spectral reflectance signatures are indicative of the presence of clay minerals, sulfates, and anhydrous Fe oxides, respectively.

This framework provides a potentially powerful tool to link secondary mineralogy to changing climatic conditions, but the extent to which these mineral assemblages correlate with specific periods in geologic time and accurately record global (as opposed to local) atmospheric and near-surface conditions remains to be tested. Gale crater, hosting a $\sim 5.5 \mathrm{~km}$ tall central mound called Mount Sharp (formally known as Aeolis Mons, Figure 1), provides a particularly fruitful place to test these ideas. Orbital data of Mount Sharp indicate a progressive change from clay-bearing to sulfate-bearing to anhydrous mineral assemblages as a function of stratigraphic height, which is a proxy for geologic time (Figures 2 and 3). As such, Gale crater may contain a microcosm of the mineralogical periods of [16] and could allow for detailed in situ characterization of the global 'drying out' of the red planet [17-19]. Alternatively, the secondary mineral changes observed in Mount Sharp could reflect changes in depositional environments due to decreasing accommodation space and changing basin geometry as the crater was filled with sediment [20]. The possibility to test global climate evolution models, along with the general diversity of the mineralogy and stratigraphy preserved within the mound observed from orbit, were primary factors in the selection of Gale crater as the landing site for NASA's Mars Science Laboratory (MSL) Curiosity rover.

Curiosity has been exploring Gale crater since its landing in August 2012 and climbing Mount Sharp since 2014. This in situ exploration has led to a significant evolution in the understanding of the geologic history of this region as well as a clearer understanding of how secondary minerals in sedimentary strata observed from orbit translate to detailed depositional and post-depositional processes inferred from rover-scale observations. Specifically, data from Curiosity allow for determining whether secondary mineral phases are detrital or authigenic (including early and late diagenetic) and the relative ages of processes that formed those minerals. It is important to note that the exploration of Gale crater alone is insufficient to determine whether ancient conditions inferred from its geologic record are indicative of processes and climatic conditions that are truly global in scale-such knowledge will only come through the exploration and stratigraphic correlation of many places across the planet-but it does provide what is currently a unique perspective on the degree to which apparent stratigraphic changes in secondary mineral assemblages can be uniquely linked to specific geological processes within the limitations of orbital and rover datasets.

The purpose of this paper is to provide a synthesis of the current understanding of the geologic context of the most abundant secondary minerals explored thus far at Gale crater, how rover-based observations compare with orbiter-based interpretations, and to discuss the implications of these findings for future landed and orbital exploration, including deposits to be explored in Jezero crater by the NASA Perseverance rover. Section 2 will review the history of exploration in this area and how perspectives of this area and Mars as a whole have changed from before landing to present. Section 3 through Section 5 
will discuss the secondary minerals that dominate Mount Sharp: clay minerals, Fe oxides, and sulfates.

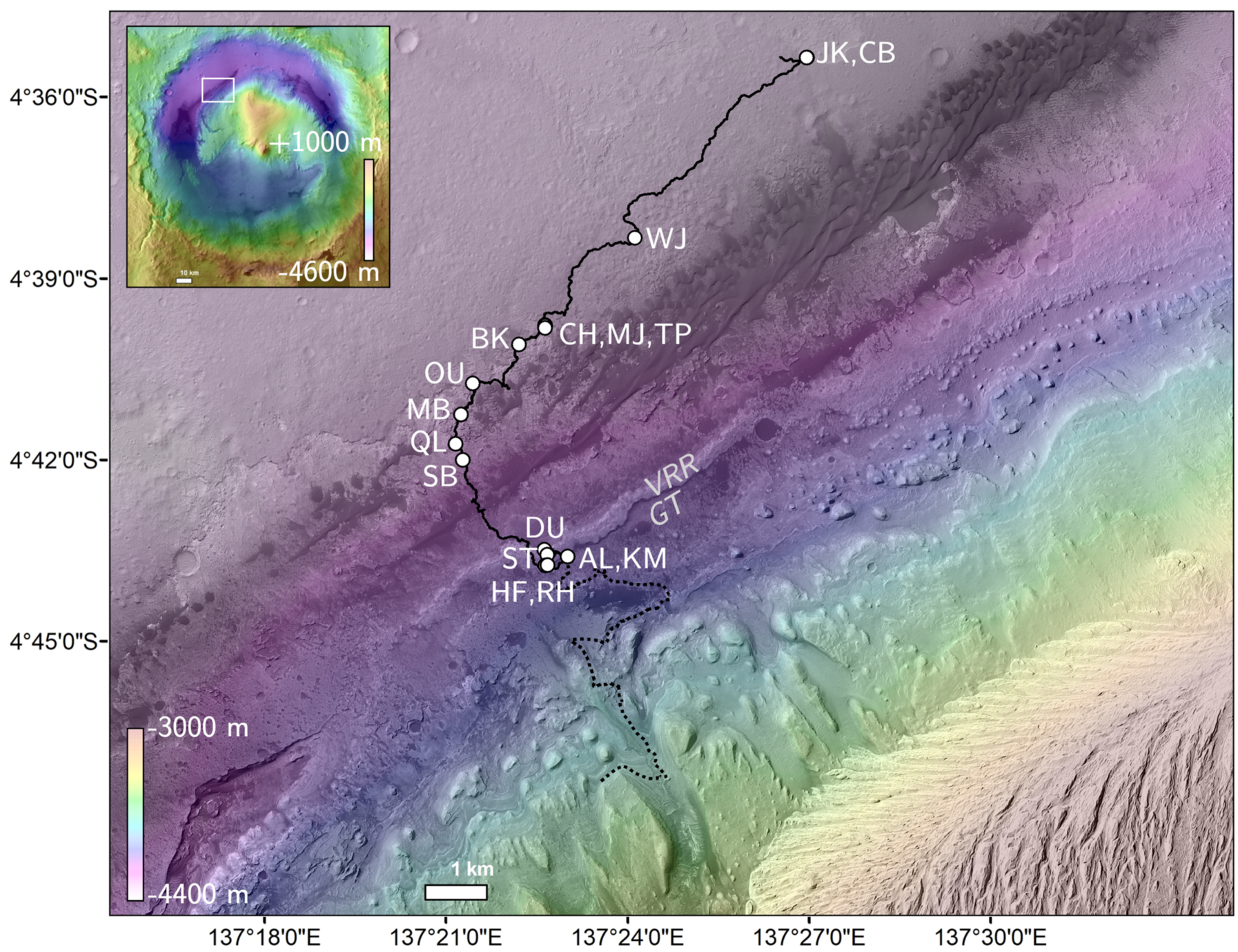

Figure 1. Elevation of northwestern Mount Sharp from the Mars Orbiter Laser Altimeter instrument, overlain on a Context Camera (CTX) image of the area. Inset shows elevation of all Gale crater, with the rover traverse region highlighted by the white square. The rover traverse route through sol 2390 (solid line) and subsequent planned route (dashed line) are shown. Labeled in gray italics are Vera Rubin Ridge (VRR) and Glen Torridon clay mineral-rich region (GT). White circles show locations of the fluvio-lacustrine drill holes through sol 2390. Abbreviations: JK: John Klein, CB: Cumberland, WJ: Windjana, CH: Confidence Hills, MJ: Mojave, TP: Telegraph Peak, BK: Buckskin, OU: Oudam, MB: Marimba, QL: Quela, SB: Sebina, DU: Duluth, ST: Stoer, HF: Highfield, RH: Rock Hall, AL: Aberlady, KM: Kilmarie.

\section{Background}

\subsection{Geologic Setting}

The geomorphological characteristics and interpreted geologic history of Gale crater and its interior deposits have been described in a number of previous remote sensing studies (e.g., [2,7,17-19,21-26]). Here we briefly summarize the geologic history of Gale crater and Mount Sharp with a focus on those attributes most relevant to Curiosity's traverse region.

Gale is a $\sim 150 \mathrm{~km}$ diameter impact crater estimated to have formed at the Late Noachian-Early Hesperian time stratigraphic boundary ( 3.5 Ga) [19], and it is situated just south of the equator $\left(-5^{\circ}\right.$ latitude) along the topographic dichotomy boundary between the smoother and younger northern lowlands and the more ancient and heavily cratered southern highlands. The most prominent feature in Gale crater is the $\sim 5.5 \mathrm{~km}$ tall central 
mound (Mount Sharp), which is not related to the central peak or peak ring formed during the impact event itself but rather was formed by post-impact sedimentary processes (Figure 1). Mount Sharp can be divided into two major stratigraphic sections (an Upper and Lower formation) that are separated by a significant erosional unconformity $([2,18,19]$, Figure 2). The age of the unconformity is unknown, and the depositional age of the Upper formation is poorly constrained due to significant erosion and a lack of craters, but it is possible the uppermost strata may be as young as Amazonian in age ( $\sim 3 \mathrm{Ga})$. In contrast, the base of the Lower formation is superposed by crater floor units that are likely Early Hesperian in age [19]. The Lower formation is also incised by numerous fluvial channels, which is consistent with it having been deposited prior to the major period of valley network formation on Mars during the Late Noachian-Hesperian time period ( 3.5 Ga).

In total, these orbital observations suggest the Lower formation, which is several kilometers in thickness, was deposited shortly after the formation of Gale crater and experienced a major erosional event during the Early Hesperian [19]. Though not definitive, it is conceivable that the Lower formation once extended to the walls of Gale crater and experienced significant lateral and vertical erosion prior to the deposition of the Upper formation [2,27]). This would imply that Gale crater transitioned from a significant sediment sink (accumulation of Lower formation) to a sediment source (significant erosion of Lower formation) and back to a sediment sink (deposition of the Upper formation) possibly within the span of several hundred million years. Interestingly, there are few channels that lead into Gale, and there are no visible outlet channels, indicating Gale is a 'closed' basin. As such, the major sources of (clastic) sediment are likely external from eolian or impact processes or internal by transport from the crater walls; sediment transported by fluvial systems originating outside the crater does not appear to have been a significant contributor. The potential for some strata of Mount Sharp to have been formed by direct chemical precipitation (e.g., layered carbonates, sulfates, or other salts) has also been of particular interest for many years, and the clay, sulfate, and Fe-oxide minerals identified from orbit are restricted to strata beneath the Upper unit.

The notion that some strata of Mount Sharp may be lacustrine in origin has been proposed for several decades (e.g., [21]), and meters-scale Mars Orbiter Camera images revealed clear orbital evidence for a complex history of sedimentary deposition and erosion during the formation and evolution of Mount Sharp [2]. However, the true depositional origins of the numerous strata of Mount Sharp were effectively unknown prior to the exploration by Curiosity, and volcanic, fluvial, eolian, and lacustrine processes have all been suggested (see summary by [19]). Indeed, orbital images reveal a wide range of surface morphologies, albedo, and bed thicknesses throughout Mount Sharp and in the Lower formation in particular, and this diversity strongly implies that multiple depositional processes have led to the construction of the mound (as discussed below). Curiosity's past and future traverse is restricted to the Lower formation, but the lithologies and mineralogy observed in that unit will record characteristics of the sediment source region(s), sediment transport mechanisms, depositional and post-depositional interactions with fluids (e.g., early and late diagenetic processes), and burial conditions.

As discussed in detail below, current observations by Curiosity reveal evidence for an ancient alluvial-fluvial-lacustrine system in Gale crater during the deposition of the Lower formation [7,8] as well as later periods of eolian deposition [4]. The stratigraphic column (Figure 2) that has been developed from Curiosity observations identifies the lowermost strata of Mount Sharp as the Murray formation (part of the larger Mount Sharp group), and to date all rover observations are consistent with sedimentary, not volcanic, processes being the dominant formation mechanisms for this portion of Mount Sharp. 


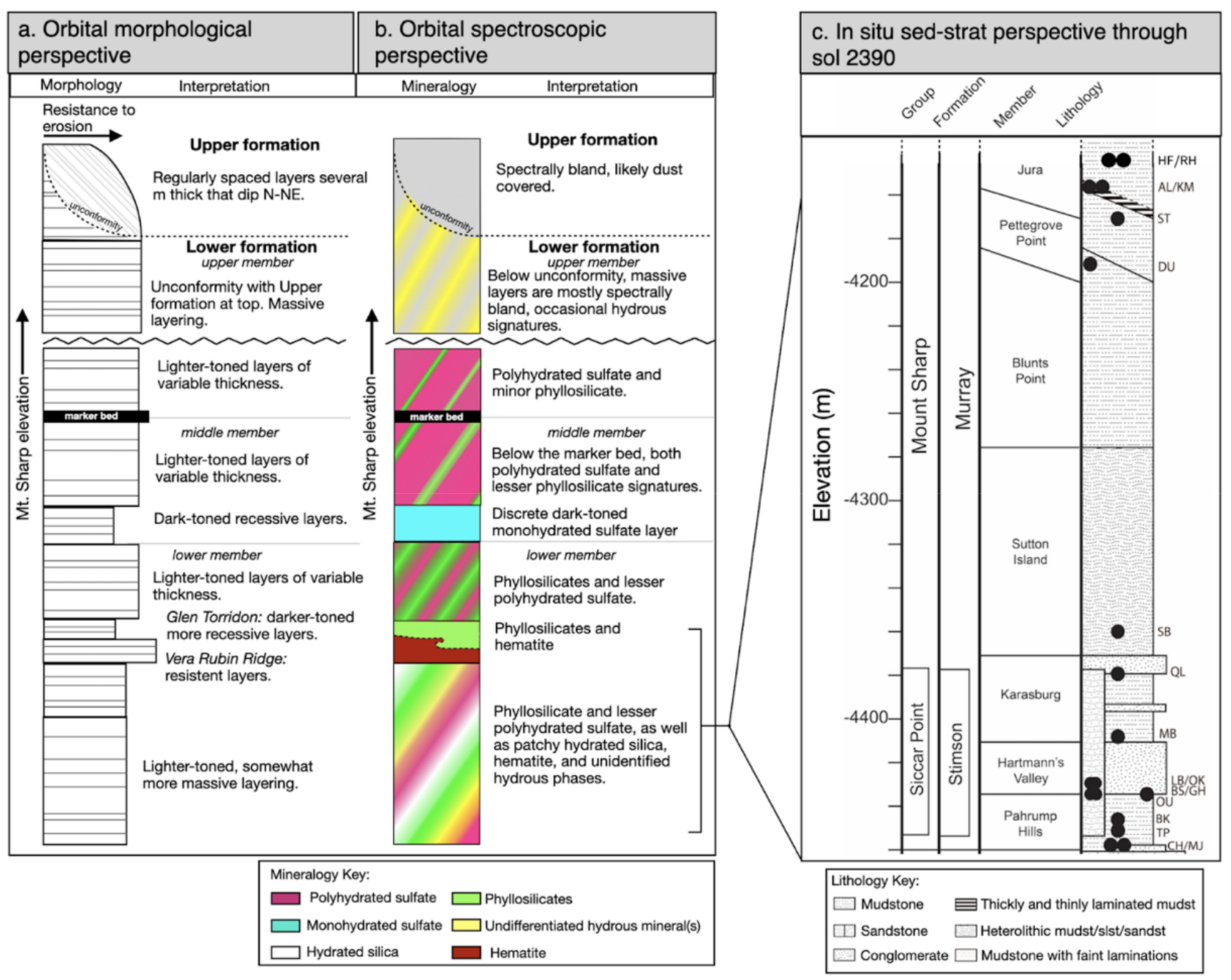

Figure 2. The layers of Mount Sharp, Gale crater, from different dataset perspectives (a) The orbital morphology of Mount Sharp, available before landing [18]. Note the locations of Glen Torridon and Vera Rubin Ridge in the lower member. (b) The orbital spectroscopic perspective of Mount Sharp [18,26,28]), available before landing as well as being continually updated with improving spectroscopic methods. The approximate extent of Mount Sharp that has been explored by Curiosity through sol 2390 is highlighted. (c) In situ geological perspective only available through landed observations. The stratigraphic column is maintained by the Science Team. The black circles mark drill holes from sol 750 through 2390. Abbreviations: JK: John Klein, CB: Cumberland, WJ: Windjana, CH: Confidence Hills, MJ: Mojave, TP: Telegraph Peak, BK: Buckskin, OU: Oudam, MB: Marimba, QL: Quela, SB: Sebina, DU: Duluth, ST: Stoer, HF: Highfield, RH: Rock Hall, AL: Aberlady, KM: Kilmarie.

While nanophase, 'X-ray amorphous' phases are common in Gale crater and have implications for aqueous and exposure histories, they also represent a broad category that can include both primary glasses and secondary alteration products (e.g., ferrihydrite and allophane). Therefore, identifying the discrete phase with short-range order is the critical focus for paragenesis and sedimentary reconstructions, and we largely focus on the crystalline secondary phases.

\subsection{Techniques for Identifying Secondary Mineralogy Remotely and In Situ}

\subsubsection{Visible-Near Infrared Reflectance Spectroscopy}

Reflectance spectra of many secondary and hydrous minerals exhibit diagnostic absorptions at visible shortwave infrared (VSWIR) $(0.4-5 \mu \mathrm{m})$ wavelengths (e.g., $[29,30])$. These absorptions are caused primarily by vibrational processes (e.g., molecular bending 
and stretching) as well as electron processes (e.g., charge transfer and crystal field splitting). Two VSWIR imaging spectrometers have observed Mount Sharp from orbit, the Observatoire pour la Minéralogie, l'Eau, les Glaces, et l'Activité (OMEGA) on the European Space Agency's Mars Express mission and the Compact Reconnaissance Imaging Spectrometer for Mars (CRISM) on NASA's Mars Reconnaissance Orbiter. CRISM measures reflected radiance from $0.36-4 \mu \mathrm{m}$ at 544 wavelengths, and because it provides the highest spatial resolution VSWIR data of Gale crater ( $\sim 18 \mathrm{~m} /$ pixel and as high as $\sim 12 \mathrm{~m} /$ pixel when using along-track oversampling [31,32], it is the focus of orbital based spectra discussed here. Reflectance spectra acquired by both instruments have revealed that many locations on Mars host secondary phases that include clay minerals, sulfates, crystalline iron oxides, opaline silica, zeolites, and carbonates $[11,12,16,18,33-36]$. As noted above, CRISM spectra of strata in Mount Sharp exhibit diverse spectral signatures indicative of the presence of clay minerals, sulfate salts, Fe oxides, and opaline silica [18,19,26,28,37].

Curiosity is also equipped with two instruments capable of collecting spectral reflectance data in the visible and shortwave infrared wavelength portion of the spectrum $(0.4-1 \mu \mathrm{m})$. The Mast Camera (Mastcam) is a multispectral (filter) imager that can observe the surface at 11 distinct wavelengths from $0.4 \mu \mathrm{m}$ to $1.04 \mu \mathrm{m}$ with pixel scales of micrometers to meters depending on distance [38,39]. The Chemistry and Camera (ChemCam laser induced breakdown spectrometer (LIBS) instrument can also be operated in "passive" mode, where it measures radiance from $0.45-0.8 \mu \mathrm{m}$ at a spectral sampling of $<1 \mathrm{~nm}$ covering $0.65 \mathrm{mrad}[40,41]$. These data are usually collected at a standoff of $2-3 \mathrm{~m}$, translating to a spot size of 1-2 $\mathrm{mm}$ [41]. This wavelength range is not sufficient to distinguish many secondary minerals that have diagnostic absorptions which occur at wavelengths longer than $1 \mu \mathrm{m}$ (e.g., clay minerals), but many iron-bearing phases do exhibit diagnostic spectral features in this range due to electronic transitions (see for example [39,42]. Both Mastcam multispectral observations and ChemCam passive spectra are converted to reflectance by observing calibration targets mounted on the exterior of the rover $[38,39,41]$.

\subsubsection{X-ray Diffraction and the CheMin Instrument}

The mineralogy of rocks and soils in Gale crater and Mount Sharp can be determined using the CheMin instrument housed in the body of the Curiosity rover. The instrument name stems from an abbreviation highlighting both the chemical and mineralogical analytical capabilities, as CheMin is equipped to acquire both X-ray fluorescence (XRF) and X-ray diffraction (XRD) data. Parts of the CheMin XRF were descoped before Curiosity's launch and, as such, the data quality is low and makes quantitative geochemistry challenging [13]. On the XRD side, the CheMin diffractometer uses a transmission geometry and collects diffracted photons from a Co-radiation source with a charge-coupled device (CCD) detector [43]. Early in the mission, drill fines (rock powder) and scooped samples of loose sediments from the surface of Mars were first sieved to $<150$ micrometers and then delivered to the CheMin inlet. As the mission progressed, our drill technique was modified and a "feed-extended" drilling method was employed, ultimately delivering rock powders straight from the drill to the CheMin inlet. After reaching the CheMin inlet, the sample aliquot is funneled into one of the 27 reusable CheMin measurement cells [43]. Samples are typically measured for a total of three nights using a Co-K $\alpha$ source, collecting 45 minor frames and reducing the signal to noise, to provide high quality diffraction patterns and ensure adequate motion of the powder in the vibrating sample cell.

Once the measured 2-dimensional diffraction ring patterns are converted to more typical 1-dimensional diffraction patterns (intensity versus $2 \theta$ ), the XRD pattern is analyzed by the CheMin team using the MDI Jade program and the FULLPAT program $[44,45]$. Most secondary minerals are readily identified from sharp reflections in the XRD pattern and are quantified with Rietveld refinement, with techniques described in detail by [13]. However, clay minerals tend to be poorly crystalline (i.e., broad reflections) and their quantification requires additional processing with a full pattern fitting technique using the FULLPAT program. On Earth, clay minerals are ubiquitous in the sedimentary rock 
record and their discrete phase identification in the laboratory with traditional benchtop X-ray diffractometers is usually performed in multiple stages of sample preparation. This extensive sample preparation in the lab includes orientating the particles to enhance the basal reflections, heating the clays to collapse any swelling layers, saturate the material with various cations (e.g., $\mathrm{Na}$ or $\mathrm{Mg}$ ), and even ethylene glycol treatments to expand the interlayers of smectites [46]. Though Curiosity is incapable of performing such techniques on the surface of Mars, CheMin is equipped with a novel sample holder that vibrates from a piezoelectric actuator drive. This vibration sets the loose sample particles in motion and randomizes the material in the cell as the analysis is performed, thus reducing the orientation concerns for phyllosilicates [47]. Clay minerals are commonly identified by the presence of a broad 001 reflection at low angles (low $2 \theta$ values). The position of the 021 peak is then examined to assess the likely occupancy of the octahedral coordination sites (e.g., diversus trioctahedral clays). Limitations still exist on Mars with the CheMin instrument, as distinguishing clay minerals with a similar structure (e.g., collapsed smectite and illite) is difficult, as is characterizing the specific cation chemistry of octahedral sites. However, the Curiosity payload includes complementary geochemical instruments (e.g., Alpha Particle X-ray Spectrometer (APXS), Sample Analysis at Mars (SAM) evolved gas analysis (EGA) that allow for elemental correlations to aid in phyllosilicate identification [48].

\section{Orbital and Rover (Sols 0-2934) Observations of Secondary Mineralogy}

\subsection{Iron Oxides}

\subsubsection{Orbital View}

Crystalline red hematite and other ferric oxides/oxyhydroxides have commonly been identified in orbital spectral datasets by one or more of four electronic absorptions between $\sim 0.4 \mu \mathrm{m}$ and $1 \mu \mathrm{m}$ (e.g., [49-52]. Three of these absorptions are single-electron transitions (cubic symmetry notation): (1) (6A1 $\rightarrow 4 \mathrm{~A} 1,4 \mathrm{E} 1$ ) between $\sim 0.4$ and $\sim 0.415 \mu \mathrm{m}$, (2) $6 \mathrm{~A} 1 \rightarrow 4 \mathrm{~T} 2$ between $\sim 0.65$ and $0.71 \mu \mathrm{m}$, and (3) $6 \mathrm{~A} 1 \rightarrow 4 \mathrm{~T} 1$ between $\sim 0.84$ and $\sim 0.91 \mu \mathrm{m}$. The fourth is a pair transition $2(6 \mathrm{~A} 1) \rightarrow 2(4 \mathrm{~T} 1)$ between $\sim 0.485$ and $\sim 0.55 \mu \mathrm{m}$. Poorly crystalline, nanophase iron oxides, including those in global Martian surface dust, are characterized only by a ferric absorption edge between $\sim 0.4$ and $\sim 0.75 \mu \mathrm{m}$, and sometimes a broad, shallow band centered near $0.85 \mu \mathrm{m}$ [53-55]. Magnetite, a mixed valence iron oxide, has spectral properties distinct from many of the other iron oxides, due in part to the surface scattering dominating at visible wavelengths caused by the delocalized nature of electrons associated with octahedral Fe. Its spectrum is generally dark and flat, with subtle Fresnel peaks near $0.65 \mu \mathrm{m}$ and a local reflectance minimum near $0.55 \mu \mathrm{m}$ [56].

At a global scale, crystalline iron oxides on Mars are most commonly detected in CRISM and OMEGA spectral datasets in association with sulfates in the Valles Marineris [16,57]. There are no unambiguous detections of magnetite in CRISM data at Mount Sharp. However, CRISM data do show several large ( $\sim \mathrm{km}$ scale) areas in the Murray formation in lower Mount Sharp are associated with spectra that have absorptions $0.55 \mu \mathrm{m}$ and $0.86 \mu \mathrm{m}$ as well as a maximum at $0.75 \mu \mathrm{m}$, which was interpreted to indicate the presence of red hematite in these regions (Figure 3, [18,28,58]. Several isolated CRISM pixels in the lower Murray formation also exhibit weak $0.86 \mu \mathrm{m}$ and $0.535 \mu \mathrm{m}$ absorptions and local maxima at $0.75 \mu \mathrm{m}$, but these detections are not spatially correlated with specific geologic features/boundaries and the spectral absorptions are the same order of magnitude as instrument noise. 


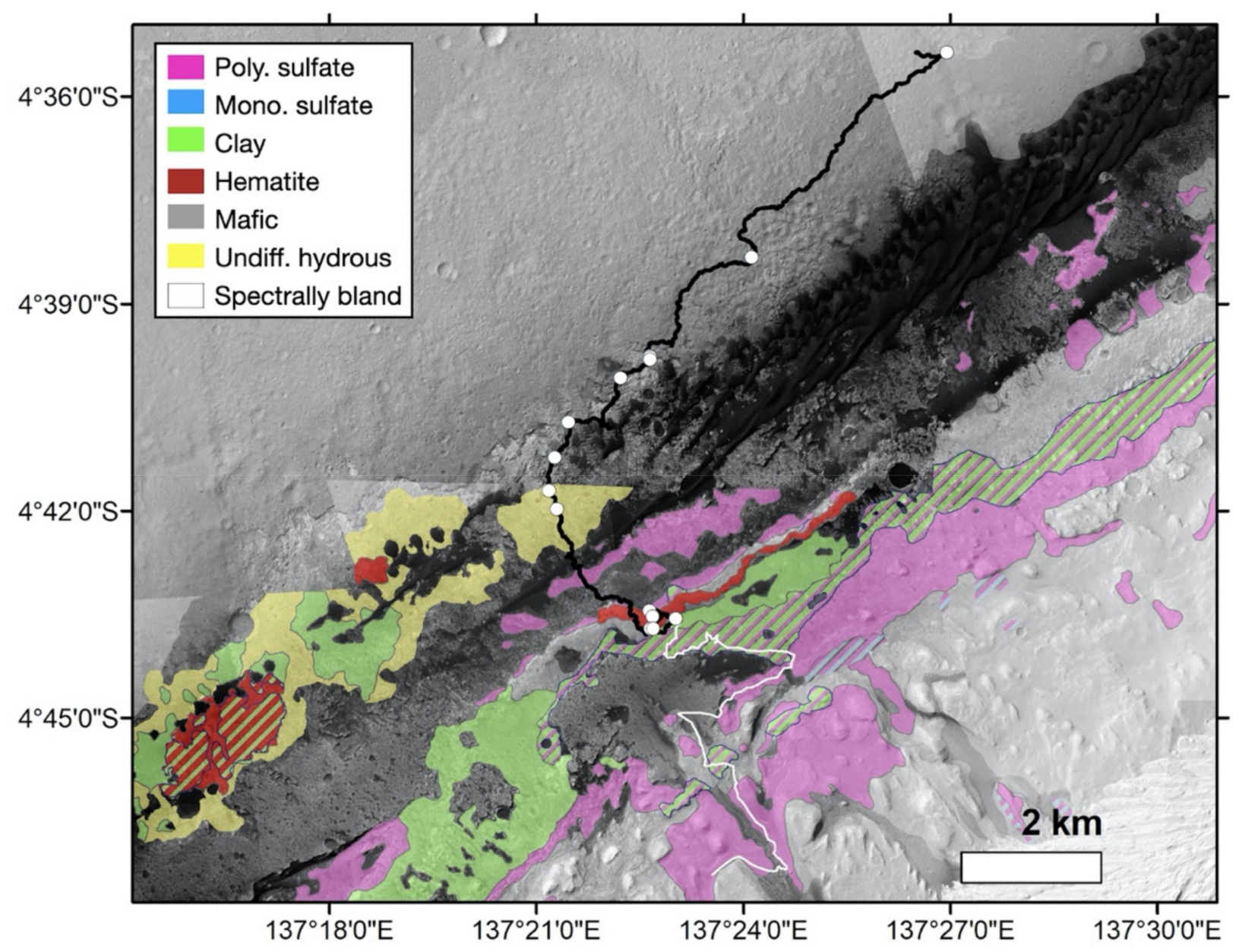

Figure 3. Orbital mineralogy of northwest Mount Sharp based on [26] and hematite detections from [28]. The rover traverse route through sol 2390 (black line) and subsequent planned route (white line) are shown. White circles show drill hole locations through sol 2390.

A feature informally named Vera Rubin ridge (VRR) is one of the areas with strong orbital spectral absorptions attributed to hematite. VRR is a topographic rise on the northwest flank of Mount Sharp and is $\sim 200 \mathrm{~m}$ wide and $\sim 6.5 \mathrm{~km}$ long in northeastsouthwest direction, approximately parallel with the base of Mount Sharp. Based on the putative CRISM hematite detection at VRR and lack of similar strong absorptions in strata immediately adjacent to the ridge, ref. [58] originally hypothesized the ridge could preserve a unique hematite-rich interval that marked a site of localized iron oxidation.

\subsubsection{In Situ Observations}

Crystalline iron oxides are visible in CheMin XRD data based on diagnostic peaks at $\sim 38.7^{\circ}, 41.6^{\circ}$, and $47.8^{\circ} 2 \theta$. Curiosity's two reflectance spectral datasets, ChemCam passive and Mastcam multispectral data, are also sensitive to the portions of the electromagnetic spectrum where diagnostic absorptions from iron oxides are present.

Data from Curiosity demonstrates that hematite is present everywhere it has been mapped from orbit, and that it is even more pervasive throughout lower Mount Sharp than predicted from orbital data alone (Figure 4). Crystalline hematite is present in almost all of the samples in the Mount Sharp group that have been drilled and analyzed by CheMin (e.g., [13]). In addition to hematite, magnetite is also detected in some of the drilled samples, and poorly crystalline iron oxides (e.g., ferrihydrite) are hypothesized to comprise a part of the X-ray amorphous component [13,45]. 


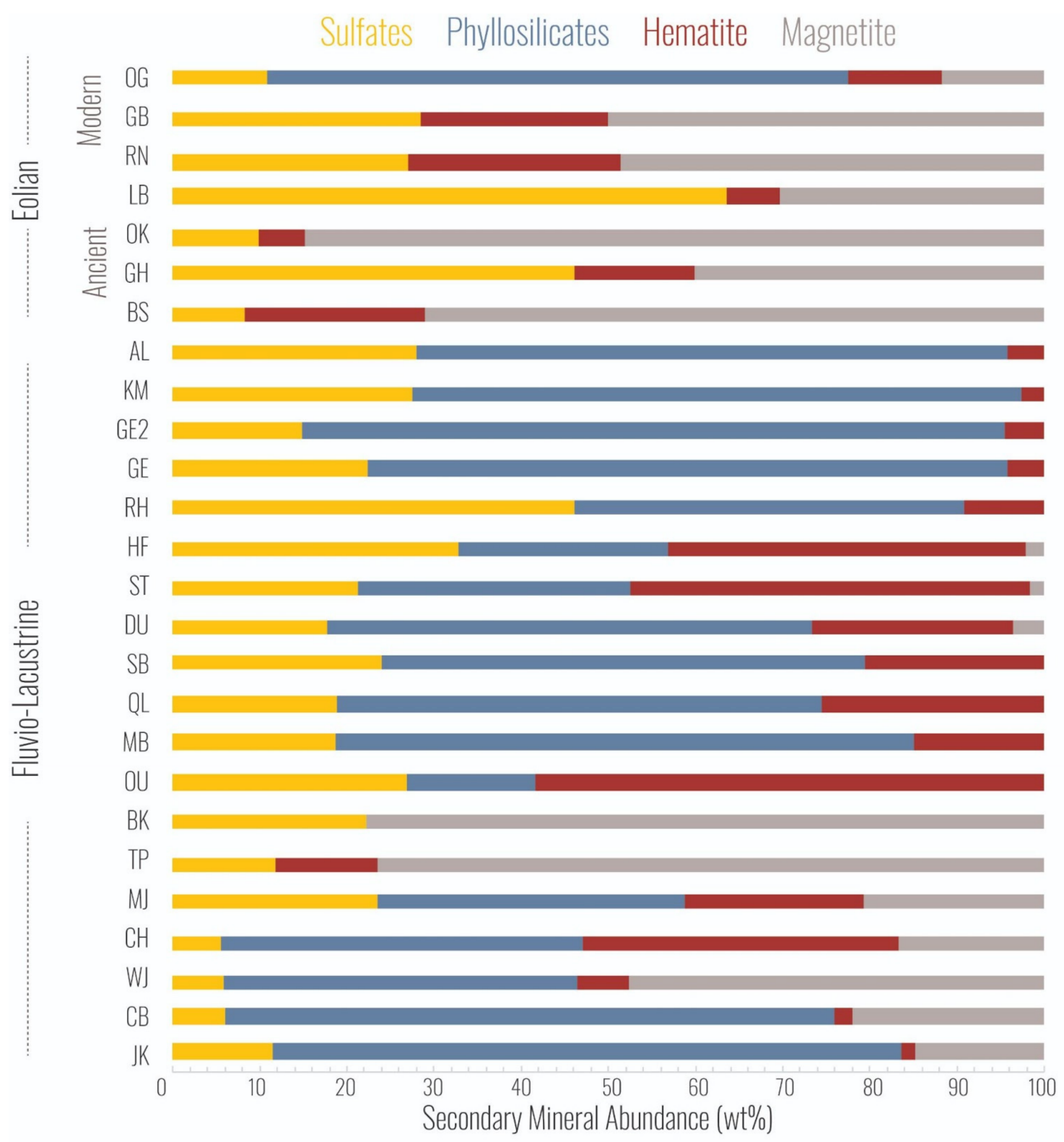

Figure 4. Major secondary mineral abundances, normalized to $100 \mathrm{wt} \%$, for all CheMin analyzed drill samples to date. Sample abbreviations are as follows; John Klein (JK), Cumberland (CB), Windjana (WJ), Confidence Hills (CH), Mojave2 (MJ), Telegraph Peak (TP), Buckskin (BK), Oudam (OU), Marimba (MB), Quela (QL), Sebina (SB), Duluth (DU), Stoer (ST), Highfield (HF), Rockhall (RH), Glen Etive (GT), Glen Etive 2 (GE2), Kilmariee (KM), Aberlady (AL), Big Sky (BS), Greenhorn (GH), Okoruso (OK), Lubango (LB), Rocknest (RN), Gobabed (GB), and Ogunquit Beach (OG). Depositional environment is indicated on the left: OG-RN are modern eolian, LB-BS are ancient eolian, and AL-JK are fluvio-lacustrine. Additional secondary phases, including opaline silica, akaganeite, and carbonate, have also been detected but are not as abundant and are not shown here.

Spectral absorptions at $0.53 \mu \mathrm{m}$ and $0.86 \mu \mathrm{m}$, consistent with the presence of hematite, were also observed in Mastcam multispectral and ChemCam passive reflectance data in many places along Curiosity's traverse across Mount Sharp, including the powdered tailings of drilled samples where hematite has been definitively detected with CheMin $[39,41,59,60]$. Coanalysis of orbital and Curiosity spectral datasets demonstrated the deep hematite-related spectral absorptions at VRR are due to a combination of slightly more hematite in the area, hematite grain size variations resulting in deeper spectral absorptions in the area, as well as relatively less sand and dust cover on the ridge [59]. Magnetite is also inferred to be 
present in some locations with low reflectance values, but no diagnostic Fresnel reflectance peaks are observed [39,41].

In all cases thus far, the red hematite observed in situ by Curiosity is intimately associated with lacustrine mudstone. When present, it is not possible to tell if the hematite is related to an iron (oxyhry)oxide phase that formed in the lake, or if it is the product of later diagenesis, and both formation mechanisms have been suggested [61-63]. At VRR, where orbital data show the deepest spectral absorptions, integration of mineralogical and chemical data with the geologic context mapped by Curiosity suggested that the distribution and grain size of hematite in the ridge, and the ridge itself, was shaped by late-stage diagenesis [64]. This conclusion is supported by CheMin data that suggest hematite crystallite sizes, which are inversely related to the width of the hematite diffraction peaks, are larger on VRR than underlying terrain, where the latter exhibit weaker spectral absorptions [13]. By extension, other locations on lower Mount Sharp with deep Fe-oxide absorptions seen from orbit may also correspond to areas of enhanced diagenesis [64].

\subsection{Clay Minerals}

\subsubsection{Orbital View}

In orbital surveys of the martian surface, phyllosilicate minerals are the most commonly detected class of secondary mineral by nearly an order of magnitude [12,65]. Of these detections, the majority are Fe-Mg smectite clays, characterized by cation-OH combination absorptions between 2.28-2.31 $\mu \mathrm{m}$ and accompanying 1.9 and occasional $1.4 \mu \mathrm{m}$ $\mathrm{H}_{2} \mathrm{O}$ overtone and combination absorptions. Nontronite (Fe-smectite) has been positively identified via high-confidence matches to spectral libraries, but many of the detections are based on an asymmetric $2.3 \mu \mathrm{m}$ absorption feature that does not match well with a single Fe-Mg phyllosilicate phase. Rather, most interpretations suggest these outcrops to be intermixed Fe- and Mg-smectite species or mixed with vermiculite or chlorites $[23,66]$. Many occurrences of Fe-Mg smectites are associated with impact craters, where the cratering process has uplifted or exposed ancient (Noachian) basement rocks $[37,65,67]$. It has been proposed that many of these clays may have formed in the subsurface via hydrothermal fluids [37], but surface formation, burial, and subsequent excavation by impacts or postimpact surface formation is also possible [67]. Fe-Mg phyllosilicates are also detected in units that exhibit clear stratification, and these occurrences may represent in-situ alteration products or accumulation of transported (i.e., detrital) clay-rich sediment $[12,65]$. In either case $\mathrm{Fe}-\mathrm{Mg}$ smectites are usually associated with the lowest stratigraphic horizons and are overlain by aluminous smectites (as identified by $\mathrm{H}_{2} \mathrm{O}$ absorptions and $\sim 2.2 \mu \mathrm{m} \mathrm{Al-OH}$ combinations absorptions) and/or a wide array of other hydrous minerals consistent with surficial weathering profiles or depositional successions $[12,37,68]$.

Fe-Mg phyllosilicate outcrops with the $2.3 \mu \mathrm{m}$ absorption are observed from orbit in Gale crater's watershed and exposed in the walls and rims of Gale and nearby craters Sharp and Herschel; their presence suggests a possible detrital origin for at least some of the clay minerals found in the sedimentary deposits within Gale crater [69]. However, most detections within Gale crater are limited to small exposures in the crater walls where bedrock has been exposed by excavation or physical weathering; most of the crater floor is obscured by dust and sand cover that limit mineral detections.

The northwestern slope of Mount Sharp is a key exception. A few isolated areas at the base of Mount Sharp and large region of several square $\mathrm{km}$, informally named Glen Torridon, in the Lower formation deposits of the sedimentary central mound has a distinctive $2.28 \mu \mathrm{m}$ Fe-OH absorption feature accompanied by a secondary $2.24 \mu \mathrm{m}$ combination band attributed to Fe-Al-OH vibrational modes, consistent with aluminum substituted nontronite (Figure 3, [18,28]). These spectral characteristics enabled a specific prediction for the clay mineral phase present in the deposit, but from orbit the origin of the clay minerals and the depositional setting of the unit remained ambiguous. Hypotheses included lacustrine deposits, ash fall, or cemented aeolian dune deposits [70]. Whether or not the phyllosilicate-bearing material was conformable to the rest of the Mount Sharp 
deposits remained an open question until in situ exploration by the Curiosity rover. Most early interpretations identified the phyllosilicate-bearing Glen Torridon as a distinct unit with a unique alteration history $[17,18]$.

\subsubsection{In Situ Observations}

Clay mineral detections by Curiosity have followed a similar story to iron oxide detections: they are detected in abundance in localities predicted from orbit, but are also much more widespread. Phyllosilicates have been detected in all but 2 of the 23 drilled fluvio-lacustrine and aeolian sedimentary rocks sampled by Curiosity in the first 3000 sols of the campaign (Figure 4, [13,71]. Consistent with orbital predictions, CheMin has found that the dominant phyllosilicate phase in Gale crater sediments are smectites [13]. Octahedral occupancy can be determined from the 021 peak position in the XRD data (Figure 5), and SAM EGA (Sample Analysis at Mars Evolved Gas Analysis) data show changes in $\mathrm{H}_{2} \mathrm{O}$ release temperature on the basis of structural changes [48,72]. The position of the 021 peak for clay minerals is sensitive to the octahedral site occupancy and has been used by authors to determine the ratio of trioctahedral to dioctahedral phases (e.g., [48]). Broadly, the smectite phases change from trioctahedral species lower in section [45] to dioctahedral phases at higher elevations, suggesting either changes in provenance, if detrital, or differences in weathering and open system alteration as the sedimentary basin filled and lithified [48]. Phyllosilicates were identified in situ for the first time in the John Klein and Cumberland drill targets, both mudstones from the Yellowknife Bay formation, the very first drilled samples of the mission [45]. Despite phyllosilicates comprising roughly a quarter of the crystalline mineral assemblage in both targets, the region is not associated with any detections from CRISM, likely due to substantial dust cover that obscures the bedrock composition from orbit $[37,73,74]$. Curiosity reached the Glen Torridon area, a topographically recessive region just south of the hematite-bearing VRR (Figure 3), 2300 sols into the mission. CRISM observations over Glen Torridon were associated with spectral absorptions consistent with $\mathrm{Al}$-substituted nontronite, a ferric smectite. Indeed, the CheMin instrument documented the highest measured phyllosilicate abundances $(\sim 30 \mathrm{wt} \%)$ in the Kilmarie and Aberlady drill targets within Glen Torridon, and confirmed they were predominantly ferric smectites, consistent with orbital predictions (Figure 4; [71]. Compared to much of the preceding traverse, where CRISM smectite detections are sparse or non-existent, the Glen Torridon region is highly eroded and relatively lacking in dust cover, as can be seen when comparing images before and after using the Dust Removal Tool (DRT). This may in part explain why mineral spectral absorptions were positively identifiable from orbit, despite the relatively small change in overall phyllosilicate abundance compared to other samples from the Murray formation.

\subsection{Sulfate Mineralogy and Spectroscopy}

\subsubsection{Orbital View}

The cation(s) and the number of structural waters $\left(\mathrm{OH}\right.$ or $\left.\mathrm{H}_{2} \mathrm{O}\right)$ attached to the sulfate $\mathrm{SO}_{4}$ anion determine the mineral type and structure. The most stable number of structural waters depends on the temperature, pressure, and relative humidity of the surrounding environment. Adding or removing structural waters causes bond restructuring that is reflected in VSWIR spectra, specifically at 1.4, 1.9-2.1 $\mu \mathrm{m}[22,30,33,75-79]$. Anhydrous sulfates lack structural water, so while they may have other spectral features (such as electronic absorptions at shorter wavelengths and $\mathrm{SO}_{4}$ stretching absorptions at $2.4 \mu \mathrm{m}$ ), the absence of strong vibrational absorptions associated with structural water makes them more difficult to detect from orbit.

Based on these spectral features, hydrous sulfates were first orbitally detected on Mars by the OMEGA instrument aboard the Mars Express Orbiter [16,33]. Distributionally, hydrous sulfates tend to be associated with Hesperian terrains [16,80]. As relatively soluble salts found in dominantly Hesperian regions, sulfates may be a harbinger of drying surface conditions in the martian sedimentary record [16] The presence of strong sulfate spectral absorptions stratigraphically above phyllosilicate spectral absorptions was a motivating 
factor in selecting Gale crater as the landing site for MSL, as the strata might span, and therefore record details of, Mars's overall climatic evolution [18,81].

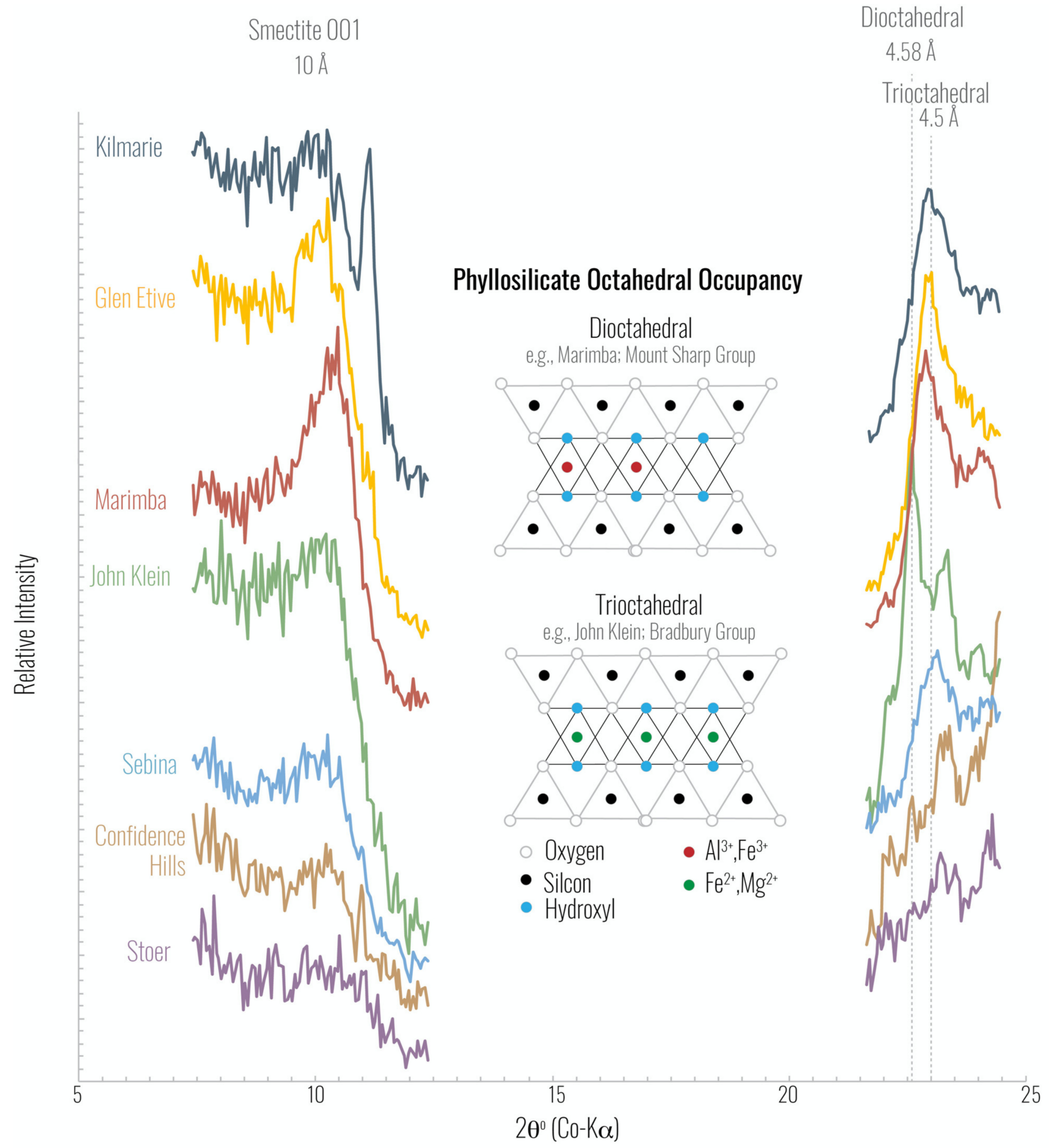

Figure 5. X-ray diffraction patterns for select mudstone drills throughout Curiosity's traverse. The $2 \theta$ range is restricted to highlight the key phyllosilicate reflections that the CheMin team uses to identify discrete clay mineral phases. Additionally, the crystal structure of smectite is illustrated to demonstrate how the octahedral site occupancy has changed throughout the stratigraphy.

The vast majority of orbital sulfate detections in Mount Sharp are attributed to Mgsulfates; the orbital spectral features are inconsistent with Ca-sulfate features and lack the Fe absorptions that would indicate Fe-sulfates $[18,26,28])$. A strong spectral slope observed 
around the Greenheugh pediment may be indicative of Fe sulfates [28] and is an area of additional investigation. There is no orbital evidence to-date of Ca-sulfates in Gale crater.

Both monohydrated $\mathrm{Mg}$-sulfate (with one structural water, also known as kieserite) and polyhydrated Mg-sulfate (2+ structural waters) have been observed in Gale crater from orbit [26]. The polyhydrated Mg-sulfate is much more widespread; the monohydrated $\mathrm{Mg}$-sulfate is almost entirely restricted to a small stratigraphic region that appears from orbit to run through the entirety of Mount Sharp (Figure 3). The presence of Mg-sulfate at the modern surface in multiple hydration states is significant. The relative humidity $(\% \mathrm{RH})$ at Gale crater is generally quite low, although it does vary throughout the day and year, with nighttime and winter experiencing increased \%RH and daytime and summer decreasing in \% RH $[82,83]$. Whether Gale crater preserves sulfates at different hydration states over geologic timescales is a major question to be addressed as the rover continues to encounter sulfates in situ.

\subsubsection{In Situ Observations Preceding the Sulfate-Rich Strata}

The direct detection of sulfates by the CheMin instrument has been common across Curiosity's traverse in Gale crater. Jarosite, an Fe-bearing sulfate, has been identified in situ in eight fluvio-lacustrine sedimentary rocks to-date. In terrestrial environments, jarosite precipitates at low $\mathrm{pH}(<4)$ and may indicate acid-sulfate solutions involved in late-stage diagenetic episodes in Gale crater [62]. Furthermore, a Hesperian age (2.12 $\pm 0.36 \mathrm{Ga})$ of the jarosite present in the Mojave2 samples suggests that sulfate-rich solutions were present late into the proposed aqueous history of Gale [84].

Ca-sulfates, including gypsum, bassanite, and anhydrite $\left(2, \frac{1}{2}\right.$, and 0 structural waters per $\mathrm{SO}_{4}$ anion, respectively), have been identified in CheMin data of fluvial-lacustrine, modern eolian, and ancient eolian samples [13]. These Ca-sulfates are readily identified from distinct reflections in XRD patterns returned from CheMin (Figure 6). These Casulfates are commonly associated with light-toned diagenetic features such as veins, voids, concretions, and alteration halos, and are also believed to be a constituent of the cementing material in some eolian and fluvio-lacustrine sedimentary rocks [85-91]. Additionally, because these common Ca-sulfates are structurally separated by their hydration state, CheMin was able to perform in situ experiments of dehydrating the phases, by warming the samples within the $\sim 6$ to $30{ }^{\circ} \mathrm{C}$ and low humidity chamber of the instrument [88]. By accounting for this sample environment in CheMin, the abundances of each discrete Ca-sulfate phase are modeled and used to provide further constraints on the sedimentary history, e.g., precipitation temperature, of Gale crater [87]. Ca-sulfate has also been detected in ChemCam data [85]. In APXS measurements, the vast majority of targets with $\mathrm{SO}_{3}$ contents $>15 \mathrm{wt} \%$ have positively correlated $\mathrm{CaO}$ and $\mathrm{SO}_{3}$ abundances, present at close to the 3:2 ratio present in Ca-sulfate by weight [92].

It is unusual that Ca-sulfates, abundant throughout Mount Sharp, cannot be identified in orbital spectra of Gale crater. The lack of Ca-sulfate in orbital data is an enduring mystery, given its abundance on the ground. Anhydrite, lacking in structural water, would not be visible in VSWIR orbital spectra, but bassanite and gypsum have spectral absorptions that should be perceptible in CRISM data. Therefore, one possible reason Ca-sulfate is not visible from orbit is that it is in this anhydrous form, at least at the optical surface, and therefore not spectrally influential. This would allow the sulfate just below the optical surface to possibly remain hydrated, as it is observed by CheMin which collects material from several $\mathrm{cm}$ depth. This is consistent with ChemCam data that suggest that the majority of Ca-sulfate veins Curiosity has explored are bassanite formed by dehydration of gypsum [85]. If the Ca-sulfate in these features is hydrated bassanite or gypsum, as may have been observed in Yellowknife Bay [93,94], then it is possible these Ca-sulfate veins and nodules represent too little areal coverage, even if widespread on the surface, to affect the orbital spectra. 


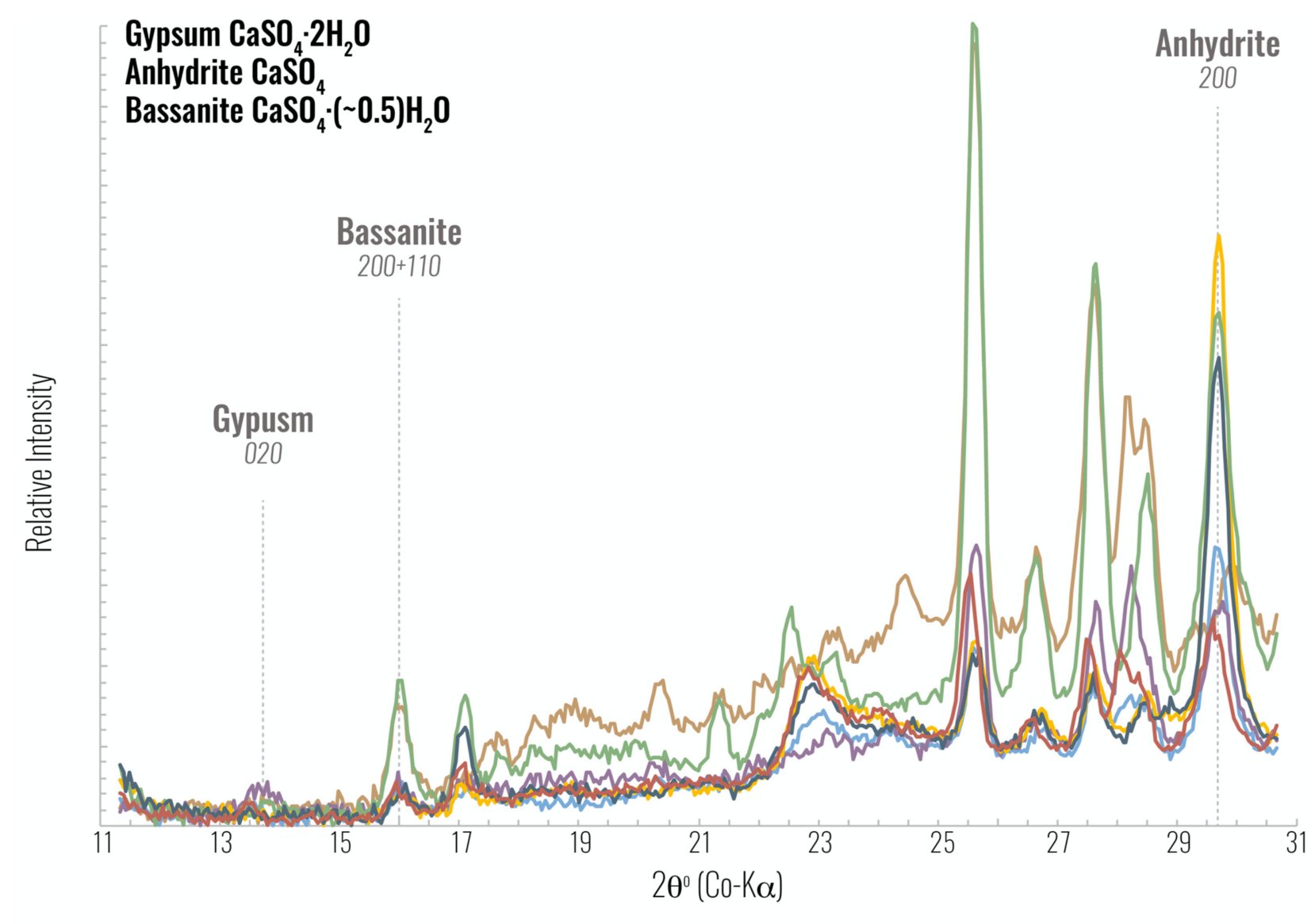

\section{Stoer Sebina Confidence Hills John Klein Marimba Glen Etive Kilmarie}

Figure 6. X-ray diffraction patterns for select mudstone drills throughout Curiosity's traverse. The $2 \theta$ range is restricted to highlight the key sulfate reflections that the CheMin team uses to identify discrete phases. The location of XRD peaks for the most common sulfate minerals identified are illustrated with dotted lines.

Mg-sulfates present an inverse paradox complementary to Ca-sulfates. Mg-sulfates are widespread in Gale crater from orbit, including in some areas the rover has already traversed [26], but they have not been clearly identified in CheMin data to-date in situ. This discrepancy is possibly the result of an X-ray amorphous, nanocrystalline structure making them difficult to detect with Curiosity's payload. Some more subtle detection methods do show evidence for Mg-sulfate in situ. APXS measurements show a positive correlation between $\mathrm{MgO}$ and $\mathrm{SO}_{3}$ in some diagenetic features in the Pahrump Hills and Hartmann's Valley members of the Murray formation [92]. No evidence of bedrock $\mathrm{Mg}$ sulfates has yet been detected in APXS [92,95]. Ref. [96] theorized that correlations between Mg and S in APXS and ChemCam data might be evidence for an enrichment in Mg-sulfate in certain Mount Sharp strata, and SAM EGA analyses have suggested the presence of Mg-sulfates, as well [97]. This may be because monohydrated Mg-sulfate $\left(\bullet 1 \mathrm{H}_{2} \mathrm{O}\right)$ is known to hydrate to an X-ray amorphous polyhydrated phase $\left(\bullet 4+\mathrm{H}_{2} \mathrm{O}\right)$ which, if exposed again to low $\% \mathrm{RH}$ (relative humidity), loses structural water but remains amorphous and polyhydrated $\left(\bullet 2 \mathrm{H}_{2} \mathrm{O}\right)$.

The relative solubility of sulfates, particularly Mg-sulfates [98], means that, wherever they are present, those strata were likely exposed to minimal water after their formation. Whether deposited in an evaporative lacustrine or subsurface groundwater environment, their presence seems to point toward low water-rock ratios and saline fluids $[62,85,86,88,89,98]$. Likewise, the solubility of sulfates means it is very unlikely these sulfates are detrital, and they were almost certainly formed within Gale crater. This makes 
the possibility of primary precipitates or diagenetic sulfates seem even more likely. Indeed, Mount Sharp's Ca-sulfates are often found in complex vein and fracture networks that clearly crosscut primary strata [90,91], as well as nodules and cements [89]. Similarly, the APXS detections of Mg-sulfate bearing nodules suggests that at least some of Gale crater's Mg-sulfates are diagenetic [33]. The variety of morphological expressions points to multiple phases of diagenetic emplacement $[45,87,90,91]$.

Overall, the sulfates observed thus far in Mount Sharp are most consistent with circumneutral aqueous conditions with minimal subsequent aqueous exposure. Although the Curiosity rover has found other evidence of localized acidic conditions [61,86], there is no evidence yet for widespread sulfates that form under acidic conditions such as $\mathrm{Al}^{3+}$ or $\mathrm{Fe}^{3+}$ sulfates. If waters were acidic, $\mathrm{Al}^{3+}$ and $\mathrm{Fe}^{3+}$ in solution would have been extremely low such that these sulfates still did not precipitate in significant amounts. The presence of small amounts of jarosite is consistent with acidic conditions in an isolated mid-Hesperian alteration event $[84,90]$.

\section{Implications for Constraining Gale Crater History \\ 4.1. Lessons Learned from Coordinated In Situ and Orbital Observations}

A primary goal of the MSL mission is to explore and quantitatively assess the habitability and environmental history preserved in the rock record at Gale crater [99]. To achieve this goal, the mission has benefited from iterative comparison of orbital and in situ data and the reinterpretation of each in the context of the other. Orbital observations provide a foundation of the mineralogy and geomorphology in a broad context, while in situ observations supply the higher resolution information needed to fully document depositional environments and geochemical conditions. In situ data from Mastcam and MAHLI (Mars Hand Lens Imager) reveal millimeter scale textural features, including sedimentary structures and cross-cutting relationships. CheMin, in coordination with APXS data, shows the composition and abundances of crystalline and amorphous materials, the full range of which cannot be observed from orbit [100-102]. These in situ data are critical for developing models that constrain fluid conditions and habitability through time at Gale crater, and complement orbital data that guide Curiosity's traverse and enable models developed from in situ data to be extrapolated to regional scales.

In situ data have shown how orbital data alone do not capture the full complexity of the aqueous history of the plains of Gale crater and lower Mount Sharp. The bulk mineralogy of the sedimentary rocks in Gale crater reflects detrital input, sorting and/or mixing during transport, minerals formed during the lacustrine phase, and minerals formed by early and late-stage subsurface diagenetic fluids. The effects of all three of these processes have been documented by Curiosity. Elemental trends coupled with grain size estimates of rocks across the plains of Aeolis Palus presented evidence of the sorting of primary detrital minerals during transport [103]. The Bradbury group has evidence of sediment source mixing $[92,104]$. CheMin data combined with sedimentological analyses demonstrated Yellowknife Bay and the lowest portions of Mt Sharp were deposited in a lacustrine environment with geochemical conditions conducive to authigenic clay formation [7,8,45,48,72]. Measurements of the distribution of diagenetic feature morphologies, size, density, and chemistry in lower Mount Sharp showed there were at least six discrete late diagenetic fluid flow events recorded thus far that overprint lacustrine mudstones and affect different extents of the stratigraphy [90]. Disentangling which phases formed in primary lacustrine, detrital, or early or late diagenetic environments is necessary to create geochemical models that track evolving lake and diagenetic fluid conditions, and therefore monitor the habitability and environmental evolution of Gale crater, over time.

The diversity of amorphous phases in Mount Sharp, including amorphous Mg-sulfate, also highlights the importance of landed missions having multiple methods to measure sample composition [102]. Amorphous phases cannot be readily detected by CheMin, but the combined perspectives of crystalline mineralogy and bulk chemistry (available from APXS) can be used to estimate the composition of the amorphous component, including 
potential presence of amorphous sulfates. This approach has been an invaluable tool to answer questions about the enigmatic amorphous phase throughout the mission [101,102]. In another technique, the DAN instrument measures hydrogen content, which, when paired with data from SAM, CheMin, and APXS, can constrain the composition of amorphous materials; this technique has been used in the Bagnold dunes [105], which are composed of $\sim 40 \mathrm{wt} \%$ amorphous phases [62,106].

VRR and Glen Torridon are excellent examples of how iterative analysis of orbital and in situ data was necessary to fully understand the geologic context of the secondary minerals in those regions, and to refine models for the geochemical evolution of Mount Sharp. Initially, the apparently isolated nature of the hematite-bearing layer in orbital data at VRR was interpreted to suggest hematite was unique to this interval, which led to the idea that it preserved a redox interface [45]. However, this hypothesis was challenged when CheMin data showed hematite was present in Mount Sharp below VRR, in areas it was not as readily apparent from orbit. After a dedicated investigation of VRR, data from across Curiosity's payload revealed the area's unique spectral and geomorphic properties were the result of interactions with late-stage diagenetic fluids, and it was not a localized interval of iron oxidation as originally hypothesized [64]. Due to the lack of obvious chemical and mineralogical differences between VRR and the underlying strata however, the nature of the diagenetic fluids was initially unconstrained, with hypotheses ranging from slightly oxidizing [64], to warm and moderately acidic [13], to potentially even reducing $[63,107,108]$.

The key to understanding diagenesis at VRR was unlocked after Curiosity's exploration of the clay-bearing Glen Torridon region. The stratigraphic relationship between VRR and Glen Torridon could not be uniquely determined from orbital data because small changes in assumptions about stratal dip resulted in major differences in the projected stratigraphic column. The refinement throughout the mission of both hypotheses and terminology applying to the stratigraphic column is shown in Figure 7. The fractured intermediate unit (FIU) was a region defined by orbit and represented the contrast between the smooth and what resembled a fractured section of the Glen Torridon region. Since traversing the GT region of the upper Murray formation, this terminology has been phased out and the members are now defined as Jura, Knockfarril Hill, and Glasgow. It was not until Curiosity's Navcam and Mastcam stereo data provided tools to accurately measure the dip of layers within VRR and Glen Torridon, as well as the discovery of corresponding facies in both regions, that it was concluded VRR and Glen Torridon were deposited at the same time and later differentiated by large-scale diagenesis [109,110]. Subsequent comparison of the secondary mineralogy in CheMin data of the clay-rich Glen Torridon region with the hematite-rich VRR provided stronger constraints on possible fluid chemistry models, and suggested the transition from hematite-bearing to clay-bearing rocks observable from orbit was due to the destruction of clays and formation of hematite by density driven, silica-poor brines sourced from the overlying sulfate-bearing unit [111]. The example of hematite in VRR and phyllosilicate in Glen Torridon mapped from orbit demonstrates again the central importance of in situ observations when inferring paleoenvironmental conditions, as diagenetic processes can have large-scale effects. Rover data in both locations showed the dominant secondary minerals reflect changes in late-stage diagenetic fluid chemistry rather than primary depositional environment. 


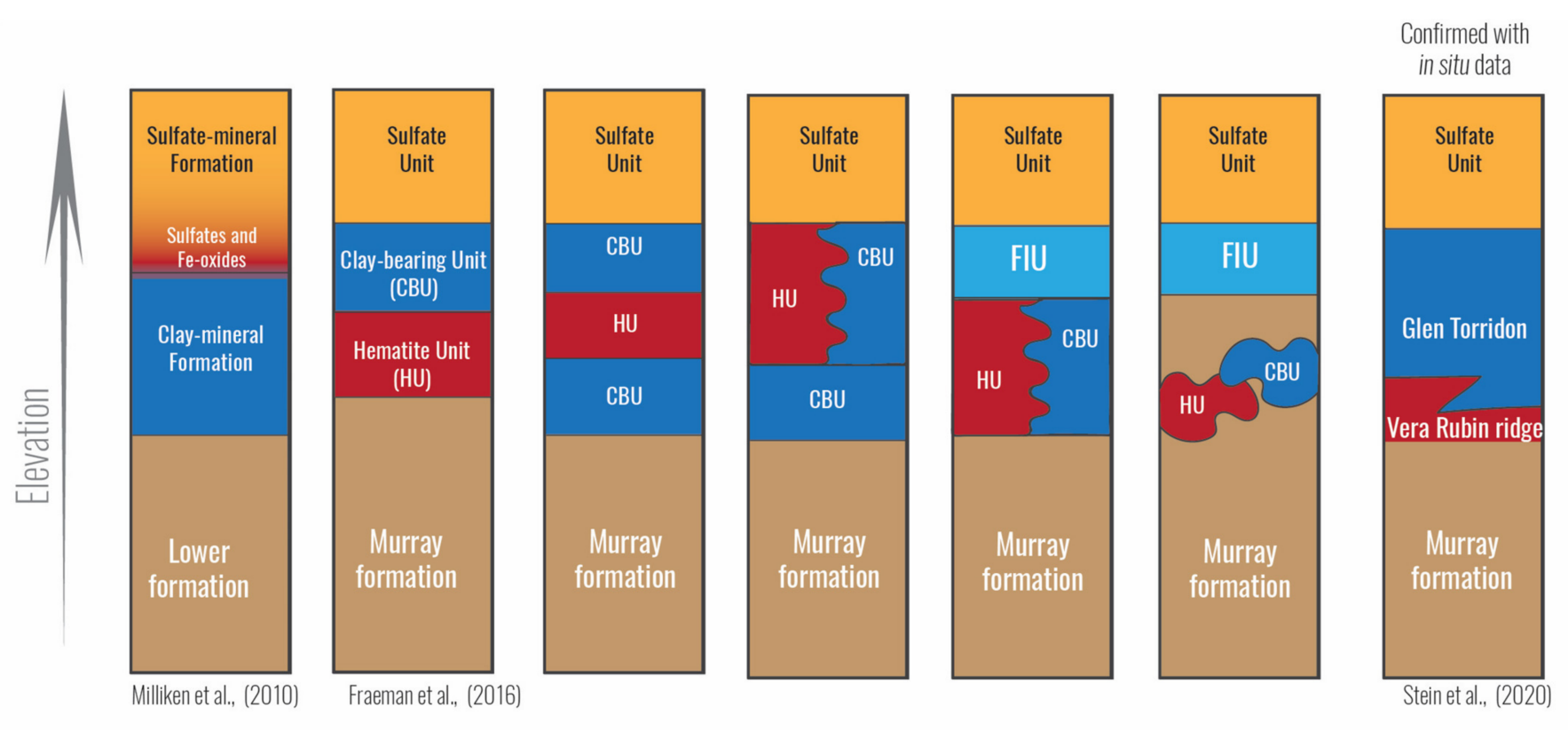

*Strat columns not to scale

Figure 7. Depiction of refinement of hypotheses over the course of Curiosity's mission $[18,28,112]$ for the stratigraphic relationship between the clay-bearing (Glen Torridon) and hematite-bearing (Vera Rubin ridge) geomorphic units. The relationship between the two was not resolved until in situ data were available, and understanding this relationship was critical for understanding the importance of diagenesis in the formation of the secondary phases observable from orbit [111]. Figure after [112].

\subsection{Predictions for Upcoming In Situ Observations of Sulfate-Rich Strata}

It is interesting that while the polyhydrated Mg-sulfates are observed in many locations and stratigraphic positions in Gale crater, they are often somewhat patchy and disconnected in the orbital perspective. This could mean that they formed by patchy, disconnected aqueous processes, either primary (e.g., a series of small lakes) or diagenetic (e.g., patchy diagenesis driven by porosity and permeability). Alternatively, the $\mathrm{Mg}$-sulfates could be more widespread and not manifesting in the orbital data everywhere that they are present. For example, laboratory work [113] shows that the presence of a significant fraction of phyllosilicates in samples with amorphous Mg-sulfate can entirely mask the presence of the Mg-sulfate in VSWIR spectral data. It is possible that Mg-sulfates are more abundant than can be seen from orbit because of the abundance of phyllosilicates in Gale crater. This possibility will be important to assess with ongoing rover observations carefully attuned to the amorphous phases.

The Curiosity rover is about to begin exploring the strata in Mount Sharp with orbital spectral absorptions interpreted to indicate an enrichment of sulfate minerals. As the Curiosity science team looks ahead to exploring the sulfate-rich strata in the coming months, it is important to reflect on lessons learned from the mission's history of interpreting orbital data in the context of detailed in situ observations. The rover will soon be approaching discrete strata clearly enriched in Mg-sulfate identified from orbit. This geologic setting represents a significant change from the sulfates seen in situ throughout the mission thus far. These strata are massive strata with yardang-like features [18], and a discrete dark-toned package of strata that bear a monohydrated Mg-sulfate (kieserite) signature from orbit [26]. These dark-toned kieserite-bearing strata are found around the mound, sandwiched between two lighter-toned layers that have varying strengths of spectral absorptions (i.e., band depths) attributed to sulfate and clay minerals. The kieserite strata are obscured by erosion and talus in many areas but overall appear to be throughgoing in the sedimentary mound of Mount Sharp. The elevation of the kieserite strata also varies widely around the mound. Given the range of estimated dips near the northwest, it is likely 
that the thickness of this layer is at least somewhat variable throughout the crater, indicative of some lateral variation in its formation process, whether it was primary or diagenetic [26]. Sulfates formed in an evaporative lacustrine setting would likely have formed in surface or near-surface pore space water which could vary within the crater and reflect a changing lake environment; post-lacustrine sulfate emplacement by groundwater flow would be largely driven by porosity and permeability and reflect strata with different exposure histories to diagenetic fluids and/or erosion and subsequent exposure to the atmosphere.

Observing the geologic setting of these Mg-sulfates in different hydration states in situ will allow distinguishing between different possible formation and preservation mechanisms. The strongest kieserite signatures, for example, appear to come from unconsolidated material accumulating in gullies in southeast Mount Sharp; loose material will have a high surface area to volume ratio, favoring hydration, so the persistence of kieserite in loose material suggests it is stable at modern conditions. Polyhydrated sulfates observable at the modern surface do not dehydrate to kieserite, but rather to a non-crystalline, X-ray amorphous form. This means that, if the orbital detections of kieserite in Gale crater are genuine, those strata have not been exposed to prolonged high humidity during their history as hydration followed by dehydration would have produced an X-ray amorphous Mg-sulfate rather than kieserite [114,115]. This precludes past exposure to frost and ice cover, as well, which would expose the strata to a $100 \% \mathrm{RH}$ environment. If the strata were exposed to such an environment, the polyhydrated and/or amorphous sulfate that would have been formed has since eroded away.

It is possible these massive sulfate deposits represent the martian environment beginning to significantly dry out, increasing salinity in martian waters, with discrete sulfate beds. Ref. [98] argue Ca- and Mg-sulfates in the Sutton Island member are early diagenetic, pre-compaction salt precipitation from brines concentrated by evaporation. Alternatively, perhaps the sulfates encountered in lower Mount Sharp are remobilized from these higher strata that flowed downward in diagenetic waters. Or perhaps all the sulfates will be determined to be diagenetic, formed from dissolution of other materials in Gale crater during burial, with stratigraphic boundaries between different mineral classes in the area representing variation in porosity and permeability more than anything else. Likewise, the specifics of this transition in situ will be uniquely informative. For example, if the dark-toned kieserite strata that expresses around Mount Sharp appears to be primary, such a deposit has significant implications for the volume of water that could be sustained at the martian surface at that time, filling much of the crater. Similarly, perhaps the onset of the sulfate strata will appear patchy with many separate onsets in situ, suggesting a reduction from a large lake to many smaller lakes as the crater environment began to dry out. However, whether primary or diagenetic, whatever process generated the bulk of these sulfates appears to have affected the entire Gale crater environment to some extent, meaning it has great significance for this area of Mars and perhaps the planet as a whole.

\subsection{Implications for Gale Crater Evolution Models}

In situ observations and our growing understanding of fluid flow within Mount Sharp have informed re-examinations of the orbital spectra. The perspective that abundant diagenetic fluid flow events can permeate hundreds of meters of Mount Sharp stratigraphy with results visible from orbit, combined with improved de-noising processes for CRISM data, motivated the creation of a mineral map of the stratigraphy around Mount Sharp as a whole [26]. When mapping other areas of Mount Sharp, the secondary mineral stratigraphy is decidedly less "layer cake" than early interpretations of the rover traverse area, with phyllosilicates and both monohydrated and polyhydrated Mg-sulfates spanning a wider stratigraphic range than is seen near the rover traverse region in northwest Gale crater. There are several possible models for lake structures that could account for this. If Gale's lake was one lacustrine system filling much of the crater whose waters evolved through time, possibly including full drying events, then some of these secondary phases that vary widely in stratigraphic position were likely a later diagenetic subsurface fluid event. 
This would prominently include the dark-toned kieserite strata, which varies in apparent thickness and stratigraphic position around the mound. In situ observations to investigate small scale textures and detailed mineral assemblages, crystallinity, and hydration states will be necessary to determine if this would have been an early diagenetic event soon after deposition, or a later event post-lithification that crosscuts stratigraphy. The position of diagenetic secondary mineral phases was likely driven first-order by porosity and permeability at the time of the fluid flow event.

Alternatively, there could have been several lakes around Mount Sharp, possibly evolving in location and size through time. In this case, the multiple sulfate deposits found around Mount Sharp could be primary, representing distinct drying events unrelated to each other, with observable evaporitic features. In other words, if the sulfates are primary lacustrine, the breadth of sulfate outcrops within Gale crater either represents different lake positions that dried contemporaneously as a response to martian climatic change, or multiple sequential lakes with independent drying processes. Further in situ observations in the coming years of the mission will allow these hypotheses to be tested.

\section{Conclusions and Implications for the Future of Mars Exploration}

5.1. Concluding Thoughts on Complementary Orbital and In Situ Perspectives

The choice to explore Gale crater was influenced in part by the hypothesis from orbital data that the rock record in Mount Sharp is a microcosm of martian climate change [18]. Assuming a traditional "layer cake" geologic model (Figure 7, left) implies that lower strata were deposited under aqueous conditions more amenable to phyllosilicate formation sometime in the late Noachian or early Hesperian, followed by a transition to more sulfateamenable, drier conditions in the Hesperian, finally to dominantly aeolian anhydrous nanophase Fe-oxide-dominated conditions in the later Hesperian or Amazonian. As Curiosity approaches the sulfate-bearing strata, it will test this hypothesis. Depositional environments and late-stage diagenetic events can often only be distinguished from in situ observations. Key sedimentological information, such as bedding geometries, grain sizes, and some diagenetic features, is too small to be resolved in orbital datasets, and therefore inherently tied to in situ observations. Integrating the fine scale textural and stratigraphic context of the secondary minerals in Gale crater will be critical to disentangle which of the multiple overlapping aqueous alteration events that we now know affected Gale crater and Mount Sharp formed secondary minerals, including the upcoming sulfates. Determining if and which sulfates are primary will be the first step in understanding how they reflect surface environmental changes.

The growing complexity in Mount Sharp's aqueous history that we continue to observe suggests that it may be difficult to confidently extrapolate models generated from data along the traverse to the larger regional or planetary scale without additional highresolution observations that can tie mineralogy to its geologic context. Nonetheless, the combined approach of orbital plus in situ data yields by far the strongest context and understanding for planetary exploration as exploration of Gale crater has demonstrated. Related to this, it is also important to recognize that having both orbital and in situ observations highlight which phases are not visible in each perspective. The views are complementary, often consistent, but sometimes highlight the gaps of the other. The gaps between orbital and in situ views have been particularly true of the sulfates in Gale crater. The visibility of Mg-sulfates only in the orbital view and Ca-sulfates only in the in situ view, as discussed above, presents a mystery. Given the scientific importance of pinpointing the origin and timing of widespread martian sulfate formation, this discrepancy in orbital and in situ views of sulfates is a priority to understand with Curiosity's upcoming exploration of the sulfate unit.

\subsection{Future Exploration of Other Regions on Mars}

The Curiosity rover has observed a breadth of secondary mineral phases in Gale crater that were created throughout the long history of lacustrine activity, burial, diagenesis, and 
exhumation. Secondary minerals, primarily Fe/Mg-phyllosilicates, $\mathrm{Ca} / \mathrm{Mg} / \mathrm{Fe}$-sulfates, $\mathrm{Fe}$ oxides including hematite, and X-ray amorphous phases, have been emplaced by a series of complex and overlapping aqueous events spanning at least into the mid-Hesperian. Characterization of the chemistry, mineralogy, crystallinity, and geologic setting of this material allows models of fluid models to be developed that represent various stages of the crater's history. This combined orbital and in situ iterative approach can influence and inform the planetary science community's consideration of future rover exploration. The types of orbital data available now allow us to plan rover traverse routes because mineralogy (valuable for science) and high-resolution topography (valuable for engineering and mobility) are readily available (Figure $2 \mathrm{a}, \mathrm{b}$ ). From the earliest stages of a mission, a strong understanding of traversable paths that keep the instrumentation safe is available, balanced with knowledge of possible areas of scientific interest. This strategy has been used for MSL at Gale crater, and this approach is now likely to be available for all future Mars landed missions. Simultaneously, however, the MSL mission has also demonstrated that phases, features, and stratigraphic relationships not visible from orbit are certain to be observed in situ. Indeed, not only are full mineral assemblages only possible to see in situ, the number and diversity of secondary phases not observable in orbital perspectives may be variable. Determining environmental and depositional settings with certainty requires detailed in situ observation.

Orbital data were critical for highlighting the regions on Mars to send MSL, and to the first order the predictions of mineralogy and mineral transitions were correct. More subtle processes are then determined from the ground perspective, including the variation in amorphous phases, variation within clay mineralogy, role of diagenesis in altering composition, and details of the depositional context. One notable example of this is determining whether phyllosilicates in Gale crater are the detrital or authigenic; determining that there is evidence for authigenic clays in Yellowknife Bay was an important development of in situ exploration and clay mineral studies which could not be achieved from orbit as observations beyond mineralogy, including trace element chemistry, co-occurring phases, and geologic setting $[72,116]$. Another important example of context only obtainable by rover observations, at present, is relative formation timing. This was best demonstrated at VRR and Glen Torridon, where rover data showed the different dominant secondary minerals observed from these regions from orbit reflected changes in late-stage diagenetic fluid chemistry rather than primary depositional environments. In other words, the specific depositional settings observed by MSL thus far have been such that elevation is a strong proxy for stratigraphic position. However, mineralogy is affected by more than just the depositional environment, and the mineral stratigraphy preserved in Mount Sharp reflects this (Figure 7). Indeed, the breadth, variability, and duration of diagenetic processes is an enormous part of Curiosity's legacy. Determining different stages of diagenesis becomes possible with detailed observations of chemical profiles, cross-cutting vein relationships, observations of hollow nodules, age dating of diagenetic phases, etc. Creating a history of diagenetic processes is critical for understanding Mars into the Hesperian and testing hypotheses about the upcoming sulfate unit.

Advancements in our understanding of Gale crater provide an important foundation for upcoming in situ exploration of the martian surface, and many of the lessons learned at Gale crater can be transferred to the Jezero crater setting. Jezero crater presents a different environment in several ways: it has a clearer inlet and subsequent delta visible from orbit than Gale crater, as well as a preserved outlet channel that breaches the eastern rim, providing clues to lake depth [117]. Although still clearly a lacustrine environment, this will have important effects on the hydrological setting compared to Gale crater. Furthermore, the Mars2020 Perseverance rover will likely face similar questions when it comes to sulfates, their stability and persistence, and their geologic setting. Although sulfates have not been mapped in Jezero crater based on orbital spectra, it is extremely likely they will be found in the lacustrine strata based on our growing understanding of how common they are in aeolian sediments and diagenetic features across Mars. Similarly, carbonates are predicted 
to be in fan structure, and observing the geologic context in situ will allow determination of whether those carbonates are detrital or formed as an authigenic cement [118-121].

Balancing orbital and in situ perspectives to fully capture an environment's mineralogy, geochemistry, and paleoenvironmental record comprise the critical frontier of martian surface exploration. Our community's expertise in martian surface processes, and when and how they differ from those on Earth, has grown enormously in the last several decades; detailed field work via landed missions is now providing great advancements in our understanding of martian evolution. The details of where and how secondary phases formed is paramount as they are valuable paleoclimatic indicators with information about an evolving planet. Secondary minerals are a primary focus of martian exploration because they are recorders of fluid processes, and provide constraints to surface water's temperature, $\mathrm{pH}$, salinity, redox state, and chemistry. Furthermore, secondary minerals are indicators of habitability, as well as possible sinks for biosignatures. Aqueous conditions constrain habitability for life as we know it, and we are at the point of martian exploration that these details of ancient aqueous conditions for multiple points across Mars are accessible. Determining the precise timing of aqueous processes takes an integrated and iterative orbital and in situ view centered on secondary minerals and their geologic context. This will be the next step in determining planetary evolution and habitability.

Author Contributions: Conceptualization, R.Y.S.; original draft preparation, R.Y.S., M.T.T., A.A.F., V.K.F. and R.E.M.; writing-review and editing, R.Y.S., M.T.T., A.A.F., V.K.F. and R.E.M.; visualization and figures, M.T.T., R.Y.S. and A.A.F.; supervision, R.Y.S.; funding acquisition, R.Y.S. All authors have read and agreed to the published version of the manuscript.

Funding: This research was funded by the Jet Propulsion Laboratory Research \& Technology Development program and the MSL participating scientist program.

Data Availability Statement: Data are publicly available on the PDS.

Acknowledgments: This research was carried out at the Jet Propulsion Laboratory, California Institute of Technology, under a contract with the National Aeronautics and Space Administration (80NM0018D0004). A.F. was funded through the MSL participating scientist program. (C) 2021. All rights reserved.

Conflicts of Interest: The authors declare no conflict of interest.

\section{References}

1. McLennan, S.; Grotzinger, J.P.; Hurowitz, J.A.; Tosca, N.J. The sedimentary cycle on early Mars. Annu. Rev. Earth Planet. Sci. 2019, 47, 91-118. [CrossRef]

2. Malin, M.C.; Edgett, K.S. Sedimentary rocks of early Mars. Science 2000, 290, 1927-1937. [CrossRef] [PubMed]

3. Grotzinger, J.P.; Milliken, R.E. The Sedimentary Rock Record of Mars: Distribution, Origins, and Global Stratigraphy; Society for Sedimentary Geology: Oklahoma, OK, USA, 2012.

4. Banham, S.G.; Gupta, S.; Rubin, D.; Watkins, J.A.; Sumner, D.Y.; Edgett, K.S.; Grotzinger, J.P.; Lewis, K.W.; Edgar, L.A.; StackMorgan, K.M.; et al. Ancient Martian aeolian processes and palaeomorphology reconstructed from the Stimson formation on the lower slope of Aeolis Mons, Gale Crater, Mars. Sedimentology 2018, 65, 993-1042. [CrossRef]

5. Banham, S.G.; Gupta, S.; Rubin, D.M.; Edgett, K.S.; Barnes, R.; Van Beek, J.; Watkins, J.A.; Edgar, L.A.; Fedo, C.M.; Williams, R.M.; et al. A Rock Record of Complex Aeolian Bedforms in a Hesperian Desert Landscape: The Stimson Formation as Exposed in the Murray Buttes, Gale Crater, Mars. J. Geophys. Res. Planets 2021, 126, 4. [CrossRef]

6. Grotzinger, J.P.; Arvidson, R.E.; Bell, J.F.; Calvin, W.; Clark, B.C.; Fike, D.A.; Golombek, M.; Greeley, R.; Haldemann, A.; Herkenhoff, K.E.; et al. Stratigraphy and sedimentology of a dry to wet eolian depositional system, Burns formation, Meridiani Planum, Mars. Earth Planet. Sci. Lett. 2005, 240, 11-72. [CrossRef]

7. Grotzinger, J.P.; Sumner, D.Y.; Kah, L.C.; Stack, K.; Gupta, S.; Edgar, L.; Rubin, D.; Lewis, K.; Schieber, J.; Mangold, N.; et al. A habitable fluvio-lacustrine environment at Yellowknife Bay, Gale Crater, Mars. Science 2013, 343, 1242777. [CrossRef] [PubMed]

8. Grotzinger, J.P.; Gupta, S.; Malin, M.C.; Rubin, D.M.; Schieber, J.; Siebach, K.; Sumner, D.Y.; Stack, K.M.; Vasavada, A.R.; Arvidson, R.E.; et al. Deposition, exhumation, and paleoclimate of an ancient lake deposit, Gale Crater, Mars. Science 2015, 350, aac7575. [CrossRef] [PubMed]

9. McLennan, S.M.; Bell, J.F.; Calvin, W.M.; Christensen, P.R.; Clark, B.C.; de Souza, P.A.; Farmer, J.; Farrand, W.H.; Fike, D.A.; Gellert, R.; et al. Provenance and diagenesis of the evaporite-bearing Burns formation, Meridiani Planum, Mars. Earth Planet. Sci. Lett. 2005, 240, 95-121. [CrossRef] 
10. Stack, K.M.; Grotzinger, J.P.; Lamb, M.P.; Gupta, S.; Rubin, D.M.; Kah, L.C.; Edgar, L.A.; Fey, D.M.; Hurowitz, J.A.; McBride, M.; et al. Evidence for plunging river plume deposits in the Pahrump Hills member of the Murray formation, Gale crater, Mars. Sedimentology 2019, 66, 1768-1802.

11. Murchie, S.; Roach, L.; Seelos, F.; Milliken, R.; Mustard, J.; Arvidson, R.; Wiseman, S.; Lichtenberg, K.; Andrews-Hanna, J.; Bishop, J.; et al. Evidence for the origin of layered deposits in Candor Chasma, Mars, from mineral composition and hydrologic modeling. J. Geophys. Res. Space Phys. 2009, 114, E00D05. [CrossRef]

12. Ehlmann, B.L.; Edwards, C.S. Mineralogy of the Martian surface. Annu. Rev. Earth Planet. Sci. 2014, 42, 291-315. [CrossRef]

13. Rampe, E.B.; Bristow, T.F.; Morris, R.V.; Morrison, S.M.; Achilles, C.N.; Ming, D.W.; Vaniman, D.T.; Blake, D.F.; Tu, V.M.; Chipera, S.J.; et al. Mineralogy of Vera Rubin ridge from the Mars science laboratory CheMin instrument. J. Geophys. Res. Planets 2020, 125. [CrossRef]

14. Summons, R.E.; Amend, J.P.; Bish, D.L.; Buick, R.; Cody, G.D.; Marais, D.J.D.; Dromart, G.; Eigenbrode, J.L.; Knoll, A.H.; Sumner, D. Preservation of martian organic and environmental records: Final report of the Mars Biosignature Working Group. Astrobiology 2011, 11, 157-181. [CrossRef] [PubMed]

15. McMahon, S.; Bosak, T.; Grotzinger, J.P.; Milliken, R.E.; Summons, R.E.; Daye, M.; Newman, S.A.; Fraeman, A.; Williford, K.H.; Briggs, D.E.G. A field guide to finding Fossils on Mars. J. Geophys. Res. Planets 2018, 123, 1012-1040. [CrossRef]

16. Bibring, J.-P.; Langevin, Y.; Mustard, J.F.; Poulet, F.; Arvidson, R.; Gendrin, A.; Gondet, B.; Mangold, N.; Pinet, P.; Forget, F.; et al. Global mineralogical and aqueous Mars history derived from OMEGA/Mars express data. Science 2006, 312, 400-404. [CrossRef] [PubMed]

17. Anderson, R.B.; Bell, J.F. Geologic mapping and characterization of Gale Crater and implications for its potential as a Mars Science Laboratory landing site. Int. J. Mars Sci. Explor. 2010, 5, 76-128. [CrossRef]

18. Milliken, R.E.; Grotzinger, J.P.; Thomson, B. Paleoclimate of Mars as captured by the stratigraphic record in Gale Crater. Geophys. Res. Lett. 2010, 37, L04201. [CrossRef]

19. Thomson, B.; Bridges, N.; Milliken, R.; Baldridge, A.; Hook, S.; Crowley, J.; Marion, G.; Filho, C.R.S.; Brown, A.; Weitz, C. Constraints on the origin and evolution of the layered mound in Gale Crater, Mars using Mars Reconnaissance Orbiter data. Icarus 2011, 214, 413-432. [CrossRef]

20. Horvath, D.G.; Andrews-Hanna, J.C. The hydrology and climate of Mars during the sedimentary infilling of Gale crater. Earth Planet. Sci. Lett. 2021, 568, 117032. [CrossRef]

21. Cabrol, N.A.; Grin, E.A.; Newsom, H.E.; Landheim, R.; McKay, C.P. Hydrogeologic evolution of Gale crater and its relevance to the exobiological exploration of Mars. Icarus 1999, 139, 235-245. [CrossRef]

22. Pelkey, S.M.; Mustard, J.F.; Murchie, S.; Clancy, R.T.; Wolff, M.; Smith, M.; Milliken, R.; Bibring, J.-P.; Gendrin, A.; Poulet, F.; et al. CRISM multispectral summary products: Parameterizing mineral diversity on Mars from reflectance. J. Geophys. Res. Space Phys. 2007, 112, E08S14. [CrossRef]

23. Wray, J.J. Gale crater: The Mars Science Laboratory/Curiosity Rover Landing Site. Int. J. Astrobiol. 2012, 12, 25-38. [CrossRef]

24. Le Deit, L.; Hauber, E.; Fueten, F.; Pondrelli, M.; Rossi, A.P.; Jaumann, R. Sequence of infilling events in Gale Crater, Mars: Results from morphology, stratigraphy, and mineralogy. J. Geophys. Res. Planets 2013, 118, 1-35. [CrossRef]

25. Grant, J.A.; Wilson, S.A.; Mangold, N.; Calef, F.; Grotzinger, J.P. The timing of alluvial activity in Gale crater, Mars. Geophys. Res. Lett. 2014, 41, 1142-1149. [CrossRef]

26. Sheppard, R.Y.; Milliken, R.E.; Parente, M.; Itoh, Y. Updated perspectives and hypotheses on the mineralogy of lower Mt. Sharp, Mars, as seen from orbit. J. Geophys. Res. Planets 2021, 126, e2020JE006372. [CrossRef]

27. Caswell, T.E.; Milliken, R.E. Evidence for hydraulic fracturing at Gale crater, Mars: Implications for burial depth of the Yellowknife Bay formation. Earth Planet. Sci. Lett. 2017, 468, 72-84. [CrossRef]

28. Fraeman, A.A.; Ehlmann, B.L.; Arvidson, R.E.; Edwards, C.S.; Grotzinger, J.P.; Milliken, R.E.; Quinn, D.; Rice, M.S. The stratigraphy and evolution of lower Mount Sharp from spectral, morphological, and thermophysical orbital data sets. J. Geophys. Res. Planets 2016, 121, 1713-1736. [CrossRef] [PubMed]

29. Farmer, V.C. The layer silicates. In The Infra-Red Spectra of Minerals; Farmer, V.C., Ed.; Mineralogical Society: London, UK, 1974.

30. Clark, R.N.; King, T.V.V.; Klejwa, M.; Swayze, G.A.; Vergo, N. High spectral resolution reflectance spectroscopy of minerals. J. Geophys. Res. Space Phys. 1990, 95, 12653-12680. [CrossRef]

31. Murchie, S.; Arvidson, R.; Bedini, P.; Beisser, K.; Bibring, J.-P.; Bishop, J.; Boldt, J.; Cavender, P.; Choo, T.; Clancy, R.T.; et al. Compact reconnaissance imaging spectrometer for Mars (CRISM) on Mars Reconnaissance Orbiter (MRO). J. Geophys. Res. Space Phys. 2007, 112, E05S03. [CrossRef]

32. Kreisch, C.; O'Sullivan, J.; Arvidson, R.; Politte, D.; He, L.; Stein, N.; Finkel, J.; Guinness, E.; Wolff, M.; Lapôtre, M. Regularization of Mars reconnaissance orbiter CRISM along-track oversampled hyperspectral imaging observations of Mars. Icarus 2016, 282, 136-151. [CrossRef]

33. Gendrin, A.; Mangold, N.; Bibring, J.-P.; Langevin, Y.; Gondet, B.; Poulet, F.; Bonello, G.; Quantin, C.; Mustard, J.; Arvidson, R.; et al. Sulfates in Martian layered terrains: The OMEGA/Mars express view. Science 2005, 307, 1587-1591. [CrossRef] [PubMed]

34. Poulet, F.; Bibring, J.-P.; Langevin, Y.; Mustard, J.; Mangold, N.; Vincendon, M.; Platevoet, B. Quantitative compositional analysis of Martian mafic regions using the Mex/OMEG: A reflectance data. Icarus 2009, 201, 69-83. [CrossRef] 
35. Mustard, J.F.; Murchie, S.; Pelkey, S.M.; Ehlmann, B.L.; Milliken, R.E.; Grant, J.A.; Bibring, J.-P.; Poulet, F.; Bishop, J.; Dobrea, E.N.; et al. Hydrated silicate minerals on Mars observed by the Mars reconnaissance orbiter CRISM instrument. Nature 2008, 454, 305-309. [CrossRef] [PubMed]

36. Ehlmann, B.; Mustard, J.; Swayze, G.A.; Clark, R.; Bishop, J.; Poulet, F.; Marais, D.; Roach, L.; Milliken, R.; Wray, J.O.; et al. Identification of hydrated silicate minerals on Mars using MRO-CRISM: Geologic context near Nili Fossae and implications for aqueous alteration. J. Geophys. Res. Planets 2009, 114, E00D08. [CrossRef]

37. Seelos, K.; Seelos, F.; Viviano, C.; Murchie, S.L.; Arvidson, R.E.; Ehlmann, B.L.; Fraeman, A. Mineralogy of the MSL curiosity landing site in Gale Crater as observed by MRO/CRISM. Geophys. Res. Lett. 2014, 41, 4880-4887. [CrossRef]

38. Bell, J.F.; Godber, A.; McNair, S.; Caplinger, M.A.; Maki, J.N.; Lemmon, M.T.; Van Beek, J.; Malin, M.C.; Wellington, D.; Kinch, K.M.; et al. The Mars science laboratory curiosity rover Mastcam instruments: Preflight and in-flight calibration, validation, and data archiving. Earth Space Sci. 2017, 4, 396-452. [CrossRef]

39. Wellington, D.F.; Bell, J.F.; Johnson, J.R.; Kinch, K.; Rice, M.S.; Godber, A.; Ehlmann, B.L.; Fraeman, A.; Hardgrove, C. The MSL Science Team visible to near-infrared MSL/Mastcam multispectral imaging: Initial results from select high-interest science targets within Gale Crater, Mars. Am. Miner. 2017, 102, 1202-1217. [CrossRef]

40. Maurice, S.; Wiens, R.C.; Saccoccio, M.; Barraclough, B.; Gasnault, O.; Forni, O.; Mangold, N.; Baratoux, D.; Bender, S.; Berger, G.; et al. The ChemCam instrument suite on the Mars science laboratory (MSL) rover: Science objectives and mast unit description. Space Sci. Rev. 2012, 170, 95-166. [CrossRef]

41. Johnson, J.R.; Bell, J.; Bender, S.; Blaney, D.; Cloutis, E.; DeFlores, L.; Ehlmann, B.; Gasnault, O.; Gondet, B.; Kinch, K.; et al. ChemCam passive reflectance spectroscopy of surface materials at the Curiosity landing site, Mars. Icarus 2015, $249,74-92$. [CrossRef]

42. Johnson, J.R.; Bell, I.J.F.; Bender, S.; Blaney, D.; Cloutis, E.; Ehlmann, B.; Fraeman, A.; Gasnault, O.; Kinch, K.; Le Mouélic, S.; et al. Constraints on iron sulfate and iron oxide mineralogy from ChemCam visible/near-infrared reflectance spectroscopy of Mt. Sharp basal units, Gale Crater, Mars. Am. Miner. 2016, 101, 1501-1514. [CrossRef]

43. Blake, D.; Vaniman, D.; Achilles, C.; Anderson, R.; Bish, D.L.; Bristow, T.F.; Chen, C.; Chipera, S.; Crisp, J.; Marais, D.D.; et al. Characterization and calibration of the CheMin mineralogical instrument on Mars science laboratory. Space Sci. Rev. 2012, 170, 341-399. [CrossRef]

44. Vaniman, D.T.; Bish, D.L.; Chipera, S.J.; Fialips, C.I.; Carey, J.W.; Feldman, W.C. Magnesium sulphate salts and the history of water on Mars. Nature 2004, 431, 663-665. [CrossRef]

45. Vaniman, D.T.; Bish, D.L.; Ming, D.W.; Bristow, T.F.; Morris, R.V.; Blake, D.F.; Chipera, S.J.; Morrison, S.M.; Treiman, A.H.; Rampe, E.B.; et al. Mineralogy of a mudstone at Yellowknife Bay, Gale Crater, Mars. Science 2014, 343, 1243480. [CrossRef]

46. Jeans, C.V.; Moore, D.M.; Reynolds, R.C. X-ray Diffraction and the Identification and Analysis of Clay Minerals; Oxford University Press: Oxford, UK, 1997; 378p.

47. Reynolds, R.C. The 24orentz-polarization factor and preferred orientation in oriented clay aggregates. Clays Clay Miner. 1986, 34, 359-367. [CrossRef]

48. Bristow, T.F.; Rampe, E.B.; Achilles, C.N.; Blake, D.F.; Chipera, S.J.; Craig, P.; Crisp, J.A.; Marais, D.J.D.; Downs, R.T.; Gellert, R.; et al. Clay mineral diversity and abundance in sedimentary rocks of Gale Crater, Mars. Sci. Adv. 2018, 4, eaar3330. [CrossRef] [PubMed]

49. Sherman, D.M.; Burns, R.G.; Burns, V.M. Spectral characteristics of the iron oxides with application to the Martian bright region mineralogy. J. Geophys. Res. Space Phys. 1982, 87, 10169-10180. [CrossRef]

50. Sherman, D.M. The electronic structures of $\mathrm{Fe}^{3+}$ coordination sites in iron oxides: Applications to spectra, bonding, and magnetism. Phys. Chem. Miner. 1985, 12, 161-175. [CrossRef]

51. Sherman, D.M.; Waite, T.D. Electronic spectra of $\mathrm{Fe}^{3+}$ oxides and oxide hydroxides in the near IR to near UV. Am. Mineral. 1985, 70, 1262-1269.

52. Morris, R.V.; Lauer, H.V.; Lawson, C.A.; Gibson, E.K.; Nace, G.A.; Stewart, C. Spectral and other physicochemical properties of submicron powders of hematite $\left(\alpha-\mathrm{Fe}_{2} \mathrm{O}_{3}\right)$, maghemite $\left(\gamma-\mathrm{Fe}_{2} \mathrm{O}_{3}\right)$, magnetite $\left(\mathrm{Fe}_{3} \mathrm{O}_{4}\right)$, goethite $(\alpha-\mathrm{FeOOH})$, and lepidocrocite $(\gamma-\mathrm{FeOOH})$. J. Geophys. Res. Space Phys. 1985, 90, 3126-3144. [CrossRef] [PubMed]

53. Bell, J.F.; Mccord, T.B.; Owensby, P.D. Observational evidence of crystalline iron oxides on Mars. J. Geophys. Res. Space Phys. 1990, 95, 14447-14461. [CrossRef]

54. Bell, J.F.; McSween, H.Y.; Crisp, J.; Morris, R.V.; Murchie, S.; Bridges, N.T.; Johnson, J.; Britt, D.T.; Golombek, M.P.; Moore, H.J.; et al Mineralogic and compositional properties of Martian soil and dust: Results from Mars pathfinder. J. Geophys. Res. Space Phys. 2000, 105, 1721-1755. [CrossRef]

55. Mustard, J.F.; Bell, J.F. New composite reflectance spectra of Mars from 0.4 to $3.14 \mu$ M. Geophys. Res. Lett. 1994, 21, 353-356. [CrossRef]

56. Izawa, M.R.; Cloutis, E.A.; Rhind, T.; Mertzman, S.A.; Applin, D.M.; Stromberg, J.M.; Sherman, D.M. Spectral reflectance properties of magnetites: Implications for remote sensing. Icarus 2018, 319, 525-539. [CrossRef]

57. Bibring, J.-P.; Langevin, Y.; Gendrin, A.; Gondet, B.; Poulet, F.; Berthé, M.; Soufflot, A.; Arvidson, R.; Mangold, N.; Mustard, J.; et al. Mars Surface Diversity as Revealed by the OMEGA/Mars Express Observations. Science 2005, 307, 1576. [CrossRef] 
58. Fraeman, A.A.; Arvidson, R.E.; Catalano, J.G.; Grotzinger, J.P.; Morris, R.V.; Murchie, S.L.; Stack, K.M.; Humm, D.C.; McGovern, J.A.; Seelos, F.P. A hematite-bearing layer in Gale Crater, Mars: Mapping an implications for past aqueous conditions. Geology 2013, 41, 1103-1106. [CrossRef]

59. Fraeman, A.A.; Johnson, J.R.; Arvidson, R.E.; Rice, M.S.; Wellington, D.F.; Morris, R.V.; Fox, V.K.; Horgan, B.H.N.; Jacob, S.R.; Salvatore, M.R.; et al. Synergistic ground and orbital observations of iron oxides on Mt. Sharp and Vera Rubin ridge. J. Geophys. Res. Planets 2020, 125. [CrossRef] [PubMed]

60. Jacob, S.R.; Wellington, D.F.; Bell, J.F.; Achilles, C.; Fraeman, A.A.; Horgan, B.; Johnson, J.R.; Maurice, S.; Peters, G.H.; Rampe, E.B.; et al. Spectral, compositional, and physical properties of the upper Murray formation and Vera Rubin ridge, Gale Crater, Mars. J. Geophys. Res. Planets 2020, 125. [CrossRef] [PubMed]

61. Hurowitz, J.A.; Grotzinger, J.P.; Fisher, W.W.; McLennan, S.M.; Milliken, R.E.; Stein, N.; Wiens, R.C. Redox stratification of an ancient lake in Gale Crater, Mars. Science 2017, 356, 1-12. [CrossRef]

62. Rampe, E.; Ming, D.; Blake, D.; Bristow, T.; Chipera, S.; Grotzinger, J.; Thompson, L. Mineralogy of an ancient lacustrine mudstone succession from the Murray formation, Gale Crater, Mars. Earth Planet. Sci. Lett. 2017, 471, 172-185. [CrossRef]

63. Horgan, B.H.; Johnson, J.R.; Fraeman, A.A.; Rice, M.S.; Seeger, C.; Bell, J.F.; Wellington, D. Diagenesis of Vera Rubin ridge, Gale Crater, Mars, from Mastcam multispectral images. J. Geophys. Res. Planets 2020, 125, e2019JE006322. [CrossRef]

64. Fraeman, A.A.; Edgar, L.A.; Rampe, E.B.; Thompson, L.M.; Frydenvang, J.; Fedo, C.M.; Catalano, J.G.; Dietrich, W.E.; Gabriel, T.S.J.; Vasavada, A.R.; et al. Evidence for a diagenetic origin of Vera Rubin ridge, Gale Crater, Mars: Summary and synthesis of curiosity's exploration campaign. J. Geophys. Res. Planets 2020, 125. [CrossRef] [PubMed]

65. Carter, J.; Poulet, F.; Bibring, J.-P.; Mangold, N.; Murchie, S. Hydrous minerals on Mars as seen by the CRISM and OMEGA imaging spectrometers: Updated global view. J. Geophys. Res. Planets 2013, 18, 1-28. [CrossRef]

66. Carter, J.; Poulet, F.; Bibring, J.-P.; Murchie, S. Detection of Hydrated Silicates in Crustal Outcrops in the Northern Plains of Mars. Science 2010, 328, 1682-1686. [CrossRef] [PubMed]

67. Sun, V.Z.; Milliken, R.E. Ancient and recent clay formation on Mars as revealed from a global survey of hydrous minerals in crater central peaks. J. Geophys. Res. Planets 2015, 120, 2293-2332. [CrossRef]

68. Bishop, J.L.; Lane, M.D.; Dyar, M.D.; Brown, A.J. Reflectance and emission spectroscopy study of four groups of phyllosilicates: Smectites, kaolinite-serpentines, chlorites and micas. Clay Miner. 2008, 43, 35-54. [CrossRef]

69. Ehlmann, B.L.; Buz, J. Mineralogy and fluvial history of the watersheds of Gale, Knobel, and Sharp craters: A regional context for the Mars science laboratory curiosity's exploration. Geophys. Res. Lett. 2015, 42, 264-273. [CrossRef]

70. Milliken, R.E.; Ewing, R.C.; Fischer, W.W.; Hurowitz, J. Wind-blown sandstones cemented by sulfate and clay minerals in Gale Crater, Mars. Geophys. Res. Lett. 2014, 41, 1149-1154. [CrossRef]

71. Tu, V.M.; Rampe, E.B.; Bristow, T.F.; Thorpe, M.T.; Clark, J.V.; Castle, N.; Fraeman, A.A.; Edgar, L.A.; McAdam, A.; Bedford, C.; et al. A Review of the Phyllosilicates in Gale Crater as Detected by the CheMin Instrument on the Mars Science Laboratory, Curiosity Rover. Minerals 2021, 11, 847. [CrossRef]

72. Bristow, T.F.; Bish, D.L.; Vaniman, D.T.; Morris, R.V.; Blake, D.F.; Grotzinger, J.P.; Rampe, E.B.; Crisp, J.; Achilles, C.N.; Ming, D.W.; et al. The origin and implications of clay minerals from Yellowknife Bay, Gale Crater, Mars. Am. Miner. 2015, 100, 824-836. [CrossRef] [PubMed]

73. Ruff, S.W.; Christensen, P.R. Bright and dark regions on Mars: Particle size and mineralogical characteristics based on Thermal Emission Spectrometer data. J. Geophys. Res. 2002, 107, 5119. [CrossRef]

74. Schmidt, M.E.; Perrett, G.M.; Bray, S.L.; Bradley, N.J.; Lee, R.E.; Berger, J.A.; Campbell, J.L.; Ly, C.; Squyres, S.W.; Tesselaar, D. Dusty rocks in Gale Crater: Assessing areal coverage and Separating dust and rock contributions in APXS analyses. J. Geophys. Res. Planets 2018, 123, 1649-1673. [CrossRef]

75. Burns, R.G. Mineralogical Applications of Crystal Field Theory; Cambridge University Press: Cambridge, UK, 1993.

76. Bishop, J.L.; Pieters, C.M.; Edwards, J.O. Infrared spectroscopic analyses on the nature of water in montmorillonite. Clay Miner. 1994, 42, 702-716. [CrossRef]

77. Cloutis, E.A.; Hawthorne, F.C.; Mertzman, S.A.; Krenn, K.; Craig, M.A.; Marcino, D.; Vilas, F. Detection and discrimination of sulfate minerals using reflectance spectroscopy. Icarus 2006, 184, 121-157. [CrossRef]

78. Chou, I.-M.; Seal, R.R.; Wang, A. The stability of sulfate and hydrated sulfate minerals near ambient conditions and their significance in environmental and planetary sciences. J. Asian Earth Sci. 2012, 62, 734-758. [CrossRef]

79. Viviano-Beck, C.E.; Seelos, F.P.; Murchie, S.L.; Kahn, E.G.; Seelos, K.D.; Taylor, H.W.; Taylor, K.; Ehlmann, B.L.; Wiseman, S.M.; Mustard, J.F.; et al. Revised CRISM spectral parameters and summary products based on the currently detected mineral diversity on Mars. J. Geophys. Res. Planets 2014, 119, 1403-1431. [CrossRef]

80. Ehlmann, B.L.; Mustard, J.F.; Murchie, S.; Bibring, J.-P.; Meunier, A.; Fraeman, A.; Langevin, Y. Subsurface water and clay mineral formation during the early history of Mars. Nature 2011, 479, 53-60. [CrossRef] [PubMed]

81. Golombek, M.P.; Grant, J.; Kipp, D.; Vasavada, A.R.; Kirk, R.L.; Fergason, R.L.; Bellutta, P.; Calef, F.; Larsen, K.R.T.; Katayama, Y.; et al. Selection of the Mars science laboratory landing site. Space Sci. Rev. 2012, 170, 641-737. [CrossRef]

82. Martin-Torres, J.; Zorzano, M.-P.; Valentín-Serrano, P.; Harri, A.-M.; Genzer, M.; Kemppinen, O.; Rivera-Valentin, E.G.; Jun, I.; Wray, J.; Madsen, M.B.; et al. Transient liquid water and water activity at Gale crater on Mars. Nat. Geosci. 2015, 8, 357-361. [CrossRef] 
83. Rivera-Valentín, E.G.; Gough, R.V.; Chevrier, V.F.; Primm, K.M.; Martínez, G.M.; Tolbert, M. Constraining the potential liquid water environment at Gale Crater, Mars. J. Geophys. Res. Planets 2018, 123, 1156-1167. [CrossRef] [PubMed]

84. Martin, P.E.; Farley, K.A.; Baker, M.B.; Malespin, C.A.; Schwenzer, S.P.; Cohen, B.; Mahaffy, P.R.; McAdam, A.C.; Ming, D.W.; Vasconcelos, P.M.; et al. A Two-step K-Ar experiment on Mars: Dating the diagenetic formation of Jarosite from Amazonian groundwaters. J. Geophys. Res. Planets 2017, 122, 2803-2818. [CrossRef]

85. Rapin, W.; Meslin, P.-Y.; Maurice, S.; Vaniman, D.; Nachon, M.; Mangold, N.; Schröder, S.; Gasnault, O.; Forni, O.; Wiens, R.; et al. Hydration state of calcium sulfates in Gale crater, Mars: Identification of bassanite veins. Earth Planet. Sci. Lett. 2016, 452, 197-205. [CrossRef]

86. Yen, A.; Ming, D.; Vaniman, D.; Gellert, R.; Blake, D.; Morris, R.; Morrison, S.; Bristow, T.; Chipera, S.; Edgett, K.; et al. Multiple stages of aqueous alteration along fractures in mudstone and sandstone strata in Gale Crater, Mars. Earth Planet. Sci. Lett. 2017, 471, 186-198. [CrossRef]

87. Vaniman, D.T.; Martínez, G.M.; Rampe, E.B.; Bristow, T.F.; Blake, D.F.; Yen, A.S.; Ming, D.W.; Rapin, W.; Meslin, P.-Y.; Morookian, J.M.; et al. Gypsum, bassanite, and anhydrite at Gale crater, Mars. Am. Miner. 2018, 103, 1011-1020. [CrossRef]

88. Nachon, M.; Mangold, N.; Forni, O.; Kah, L.; Cousin, A.; Wiens, R.; Anderson, R.; Blaney, D.; Blank, J.; Calef, F.; et al. Chemistry of diagenetic features analyzed by ChemCam at Pahrump Hills, Gale Crater, Mars. Icarus 2016, 281, 121-136. [CrossRef]

89. L'Haridon, J.; Mangold, N.; Meslin, P.-Y.Y.; Johnson, J.R.; Rapin, W.; Forni, O. Chemical variability in mineralized veins observed by ChemCam on the lower slopes of Mount Sharp in Gale crater, Mars. Icarus 2018, 311, 69-86. [CrossRef]

90. Sun, V.; Stack, K.M.; Kah, L.C.; Thompson, L.; Fischer, W.; Williams, A.J.; Johnson, S.S.; Wiens, R.C.; Kronyak, R.E.; Nachon, M.; et al. Late-stage diagenetic concretions in the Murray formation, Gale Crater, Mars. Icarus 2018, 321, 866-890. [CrossRef]

91. Kronyak, R.E.; Kah, L.C.; Edgett, K.S.; VanBommel, S.J.; Thompson, L.M.; Wiens, R.C. Mineral-filled fractures as indicators of multigenerational fluid flow in the Pahrump Hills member of the Murray Formation, Gale Crater, Mars. Earth Space Sci. 2019, 6, 238-265. [CrossRef]

92. Berger, J.A.; Gellert, R.; Boyd, N.I.; King, P.L.; McCraig, M.A.; O'Connell-Cooper, C.D.; Schmidt, M.E.; Spray, J.G.; Thompson, L.M.; Vanbommel, S.J.V.; et al. Elemental composition and chemical evolution of geologic materials in Gale Crater, Mars: APXS results from Bradbury landing to the Vera Rubin ridge. J. Geophys. Res. Planets 2020, 125. [CrossRef]

93. Rice, M.S.; Bell, I.; Godber, A.; Wellington, D.; Fraeman, A.A.; Johnson, J.R.; Grotzinger, J.P. Mastcam multispectral imaging results from the Mars science laboratory investigation in Yellowknife Bay. In Proceedings of the European Planetary Science Congress, London, UK, 8-13 September 2013.

94. Nachon, M.; Clegg, S.; Mangold, N.; Schröder, S.; Kah, L.C.; Dromart, G.; Ollila, A.; Johnson, J.; Oehler, D.Z.; Bridges, J.C.; et al. Calcium sulfate veins characterized by ChemCam/Curiosity at Gale Crater, Mars. J. Geophys. Res. Planets 2014, 119, 1991-2016. [CrossRef]

95. VanBommel, S.J.; Gellert, R.; Berger, J.A.; Thompson, L.M.; Edgett, K.S.; McBride, M.J.; Campbell, J.L. Modeling and mitigation of sample relief effects applied to chemistry measurements by the Mars science laboratory alpha particle X-ray spectrometer. X-ray Spectrom. 2017, 46, 229-236. [CrossRef]

96. Rapin, W.; Ehlmann, B.L.; Dromart, G.; Schieber, J.; Thomas, N.; Fischer, W.W.; Fox, V.K.; Stein, N.T.; Nachon, M.; Clark, B.C.; et al. An interval of high salinity in ancient Gale crater lake on Mars. Nat. Geosci. 2019, 12, 889-895. [CrossRef]

97. Sutter, B.; McAdam, A.C.; Mahaffy, P.R.; Ming, D.W.; Edgett, K.S.; Rampe, E.B.; Eigenbrode, J.L.; Franz, H.B.; Freissinet, C.; Grotzinger, J.P.; et al. Evolved gas analyses of sedimentary rocks and eolian sediment in Gale Crater, Mars: Results of the Curiosity rover's sample analysis at Mars instrument from Yellowknife Bay to the Namib Dune. J. Geophys. Res. Planets 2017, 122, 2574-2609. [CrossRef]

98. Tosca, N.J.; McLennan, S.; Dyar, M.D.; Sklute, E.C.; Michel, F.M. Fe oxidation processes at Meridiani Planum and implications for secondary Fe mineralogy on Mars. J. Geophys. Res. Space Phys. 2008, 113, E05005. [CrossRef]

99. Grotzinger, J.P.; Crisp, J.; Vasavada, A.R.; Anderson, R.C.; Baker, C.J.; Barry, R.; Blake, D.F.; Conrad, P.; Edgett, K.; Ferdowski, B.; et al. Mars science laboratory mission and science investigation. Space Sci. Rev. 2012, 170, 5-56. [CrossRef]

100. Morrison, S.M.; Downs, R.T.; Blake, D.F.; Vaniman, D.T.; Ming, D.W.; Hazen, R.M.; Treiman, A.H.; Achilles, C.N.; Yen, A.S.; Morris, R.V.; et al. Crystal chemistry of martian minerals from Bradbury landing through Naukluft Plateau, Gale Crater, Mars. Am. Miner. 2018, 103, 857-871. [CrossRef]

101. Achilles, C.N.; Rampe, E.B.; Downs, R.T.; Bristow, T.F.; Ming, D.W.; Morris, R.V.; Vaniman, D.T.; Blake, D.F.; Yen, A.S.; McAdam, A.C.; et al. Evidence for multiple diagenetic episodes in ancient fluvial-lacustrine sedimentary rocks in Gale Crater, Mars. J. Geophys. Res. Planets 2020, 125. [CrossRef]

102. Smith, R.J.; McLennan, S.M.; Achilles, C.N.; Dehouck, E.; Horgan, B.H.N.; Mangold, N.; Rampe, E.B.; Salvatore, M.; Siebach, K.L.; Sun, V. X-ray amorphous components in sedimentary rocks of Gale Crater, Mars: Evidence for ancient formation and long-lived aqueous activity. J. Geophys. Res. Planets 2021, 126, e2020JE006782. [CrossRef]

103. Siebach, K.L.; Baker, M.B.; Grotzinger, J.P.; McLennan, S.M.; Gellert, R.; Thompson, L.M.; Hurowitz, J.A. Sorting out compositional trends in sedimentary rocks of the Bradbury group (Aeolis Palus), Gale crater, Mars. J. Geophys. Res. Planets 2017, 122, $295-328$. [CrossRef] 
104. Treiman, A.H.; Bish, D.L.; Vaniman, D.T.; Chipera, S.J.; Blake, D.F.; Ming, D.W.; Morris, R.V.; Bristow, T.F.; Morrison, S.; Baker, M.B.; et al. Mineralogy, provenance, and diagenesis of a potassic basaltic sandstone on Mars: CheMin X-ray diffraction of the Windjana sample (Kimberley area, Gale Crater). J. Geophys. Res. Planets 2015, 121, 75-106. [CrossRef]

105. Gabriel, T.S.J.; Hardgrove, C.; Czarnecki, S.; Rampe, E.B.; Rapin, W.; Achilles, C.N.; Sullivan, D.; Nowicki, S.F.; Thompson, L.; Litvak, M.; et al. Water abundance of dunes in Gale Crater, Mars from active neutron experiments and implications for amorphous phases. Geophys. Res. Lett. 2018, 45, 12766-12775. [CrossRef]

106. Achilles, C.N.; Downs, R.T.; Ming, D.W.; Rampe, E.B.; Morris, R.V.; Treiman, A.H.; Morrison, S.M.; Blake, D.F.; Vaniman, D.T.; Ewing, R.C.; et al. Mineralogy of an active eolian sediment from the Namib dune, Gale Crater, Mars. J. Geophys. Res. Planets 2017, 122, 2344-2361. [CrossRef]

107. David, G.; Cousin, A.; Forni, O.; Meslin, P.-Y.; Dehouck, E.; Mangold, N.; L'Haridon, J.; Rapin, W.; Gasnault, O.; Grotzinger, J.P.; et al. Analyses of High-Iron Sedimentary Bedrock and Diagenetic Features Observed With ChemCam at Vera Rubin Ridge, Gale Crater, Mars: Calibration and Characterization. J. Geophys. Res. Planets 2020, 125, 10. [CrossRef]

108. Frydenvang, J.; Mangold, N.; Wiens, R.C.; Fraeman, A.A.; Edgar, L.A.; Fedo, C.; L'Haridon, J.; Bedford, C.C.; Gupta, S.; Grotzinger, J.P.; et al. The chemostratigraphy of the Murray formation and role of diagenesis at Vera Rubin ridge in Gale Crater, Mars, as observed by the ChemCam instrument. J. Geophys. Res. Planets 2020, e2019JE006320. [CrossRef]

109. Edgar, L.A.; Fedo, C.M.; Gupta, S.; Banhman, S.G.; Fraeman, A.A.; Grotzinger, J.P.; Stack, K.M.; Stein, N.T.; Bennett, K.A.; RiveraHernández, F.; et al. A lacustrine paleoenvironment recorded at Vera Rubin ridge, Gale Crater: Overview of the sedimentology and stratigraphy observed by the Mars Science Laboratory Curiosity rover. J. Geophys. Res. Planets 2020, 125, e2019JE006307. [CrossRef]

110. Stein, N.T.; Quinn, D.P.; Grotzinger, J.P.; Fedo, C.; Ehlmann, B.L.; Stack, K.M.; Edgar, L.A.; Fraeman, A.A.; Deen, R. Regional structural orientation of the mount sharp group revealed by in situ dip measurements and stratigraphic correlations on the Vera Rubin ridge. J. Geophys. Res. Planets 2020, 125, e2019JE006298. [CrossRef]

111. Bristow, T.F.; Grotzinger, J.P.; Rampe, E.B.; Cuadros, J.; Chipera, S.J.; Downs, G.W.; Fedo, C.M.; Frydenvang, J.; McAdam, A.C.; Morris, R.V.; et al. Brine-driven destruction of clay minerals in Gale crater, Mars. Science 2021, 373, 198-204. [CrossRef] [PubMed]

112. Stein, N.; Grotzinger, J.; Schieber, J.; Mangold, N.; Hallet, B.; Newsom, H.; Stack, K.; Berger, J.; Thompson, L.; Siebach, K. Desiccation cracks provide evidence of lake drying on Mars, Sutton Island member, Murray formation, Gale Crater. Geology 2018, 46, 515-518. [CrossRef]

113. Sheppard, R.Y.; Milliken, R.E.; Robertson, K. Presence of clay minerals can obscure spectral evidence of Mg sulfates: Implications for orbital observations of Mars. In Proceedings of the 52nd Lunar and Planetary Science Conference, The Woodlands, TX, USA, 15-19 March 2021.

114. Vaniman, D.T.; Chipera, S.J. Transformations of Mg- and Ca-sulfate hydrates in Mars regolith. Am. Miner. 2006, 91, 1628-1642. [CrossRef]

115. Chipera, S.J.; Vaniman, D.T. Experimental stability of magnesium sulfate hydrates that may be present on Mars. Geochim. Cosmochim. Acta 2007, 71, 241-250. [CrossRef]

116. Bristow, T.F.; Milliken, R.E. Terrestrial perspective on authigenic clay mineral production in ancient Martian lakes. Clays Clay Miner. 2011, 59, 339-358. [CrossRef]

117. Goudge, T.A.; Mustard, J.F.; Head, J.W.; Fassett, C.I.; Wiseman, S.M. Assessing the mineralogy of the watershed and fan deposits of the Jezero crater paleolake system, Mars. J. Geophys. Res. Planets 2015, 120, 775-808. [CrossRef]

118. Goudge, T.A.; Milliken, R.E.; Head, J.W.; Mustard, J.F.; Fassett, C.I. Sedimentological evidence for a deltaic origin of the western fan deposit in Jezero crater, Mars and implications for future exploration. Earth Planet. Sci. Lett. 2017, 458, 357-365. [CrossRef]

119. Horgan, B.H.; Anderson, R.B.; Dromart, G.; Amador, E.S.; Rice, M.S. The mineral diversity of Jezero crater: Evidence for possible lacustrine carbonates on Mars. Icarus 2019, 339, 113526. [CrossRef]

120. Brown, A.J.; Viviano, C.E.; Goudge, T.A. Olivine-carbonate mineralogy of the Jezero Crater region. J. Geophys. Res. Planets 2020, 125, e2019JE006011. [CrossRef] [PubMed]

121. Stack, K.M.; Williams, N.R.; Calef, F.; Sun, V.Z.; Williford, K.H.; Farley, K.A.; Eide, S.; Flannery, D.; Hughes, C.; Jacob, S.R.; et al. Photogeologic map of the perseverance rover field site in Jezero Crater constructed by the Mars 2020 science team. Space Sci. Rev. 2020, 216, 1-47. [CrossRef] [PubMed] 